\title{
Valorization of Apple Peels through the Study of the Effects on the Amyloid Aggregation Process of k-Casein
}

\author{
Valeria Guarrasi ${ }^{1, *, \dagger}$, Giacoma Cinzia Rappa ${ }^{1, \dagger}{ }^{\dagger}$, Maria Assunta Costa ${ }^{1}\left(\mathbb{D}\right.$, Fabio Librizzi ${ }^{1}$, Marco Raimondo ${ }^{1}$, \\ Vita Di Stefano ${ }^{2} \mathbb{D}$, Maria Antonietta Germanà ${ }^{3}$ and Silvia Vilasi ${ }^{1}$ \\ 1 Istituto di Biofisica, Consiglio Nazionale delle Ricerche, Via Ugo La Malfa 153, 90146 Palermo, Italy; \\ cinziarp@hotmail.it (G.C.R.); mariaassunta.costa@cnr.it (M.A.C.); fabio.librizzi@cnr.it (F.L.); \\ raimondo.marco@gmail.com (M.R.); silvia.vilasi@cnr.it (S.V.) \\ 2 Dipartimento Scienze e Tecnologie Biologiche Chimiche e Farmaceutiche, Università degli Studi di Palermo, \\ Via Archirafi 32, 90123 Palermo, Italy; vita.distefano@unipa.it \\ 3 Dipartimento di Scienze Agrarie, Alimentari e Forestali, Università degli Studi di Palermo, \\ Viale delle Scienze Ed. 4, 90128 Palermo, Italy; mariaantonietta.germana@unipa.it \\ * Correspondence: valeria.guarrasi@ibf.cnr.it; Tel.: +39-0916809356 \\ + These authors contributed equally to this work.
}

check for updates

Citation: Guarrasi, V.; Rappa, G.C. Costa, M.A.; Librizzi, F.; Raimondo, M.; Di Stefano, V.; Germanà, M.A.; Vilasi, S. Valorization of Apple Peels through the Study of the Effects on the Amyloid Aggregation Process of K-Casein. Molecules 2021, 26, 2371. https://doi.org/10.3390/ molecules 26082371

Academic Editors: Simona Fabroni, Krystian Marszałek and Aldo Todaro

Received: 6 March 2021

Accepted: 15 April 2021

Published: 19 April 2021

Publisher's Note: MDPI stays neutral with regard to jurisdictional claims in published maps and institutional affiliations.

Copyright: (c) 2021 by the authors. Licensee MDPI, Basel, Switzerland. This article is an open access article distributed under the terms and conditions of the Creative Commons Attribution (CC BY) license (https:/ / creativecommons.org/licenses/by/ $4.0 /)$.

\begin{abstract}
Waste valorization represents one of the main social challenges when promoting a circular economy and environmental sustainability. Here, we evaluated the effect of the polyphenols extracted from apple peels, normally disposed of as waste, on the amyloid aggregation process of $\mathrm{k}$-casein from bovine milk, a well-used amyloidogenic model system. The effect of the apple peel extract on protein aggregation was examined using a thioflavin T fluorescence assay, Congo red binding assay, circular dichroism, light scattering, and atomic force microscopy. We found that the phenolic extract from the peel of apples of the cultivar "Fuji", cultivated in Sicily (Caltavuturo, Italy), inhibited k-casein fibril formation in a dose-dependent way. In particular, we found that the extract significantly reduced the protein aggregation rate and inhibited the secondary structure reorganization that accompanies k-casein amyloid formation. Protein-aggregated species resulting from the incubation of $\mathrm{k}$-casein in the presence of polyphenols under amyloid aggregation conditions were reduced in number and different in morphology.
\end{abstract}

Keywords: polyphenolic extract; fruit waste; $\mathrm{k}$-casein amyloid aggregation

\section{Introduction}

The recycling and utilization of agricultural wastes is considered to be an important step in environmental sustainability and agricultural development as well as in promoting a circular economy [1]. Large amounts of residue with high levels of organic matter cause serious environmental pollution if discarded or disposed of improperly [2].

In this regard, an important opportunity is provided by the valorization and recycling of peels from apples, which are a rich source of bioactive compounds, like polyphenols [3]. In fact, similar to the whole fruit, the apple peel polyphenol content includes abundant amounts of flavan-3-ols/procyanidines, phenolic acids, flavonols, dihydrochalcones, and anthocyanins [4], known for their beneficial effects in human health [5]. There is evidence that apple polyphenols are strong antioxidants [6] and have, among other benefits, antitumor [7], anti-allergy [8], and life-extending properties [9].

Extensive research demonstrated how the polyphenols present in apples are highly promising as potential therapeutics for disorders resulting from protein amyloid aggregation, the process at the basis of severe neurodegenerative diseases, like Parkinson's, Alzheimer's (AD), and Huntington's disease [10-13]. These pathologies are characterized by the conversion of a normally soluble protein into an insoluble aggregated form, with further deposition onto a cross- $\beta$ fibrillary structure [14-17]. A crucial feature of amyloidosis is the complex polymorphism of the species formed whose ultrastructure and 
morphology are strictly correlated to their specific toxic potentiality $[18,19]$. The specific low-molecular-weight oligomers that form during the intermediate steps of the process are thought to play a crucial role in interacting with cell membranes and producing reactive oxygen species (ROS), thus causing cellular function impairment that ultimately leads to the death of the involved cells [20-22]. Thereby, the polyphenols known for their marked antioxidant properties are very effective at fighting the oxidative stress associated with amyloid toxicity [23-25].

An increasing number of studies have demonstrated how several specific polyphenols present in apples, including quercetin, procyanidins, (-)-epigallocatechin-3-gallate (EGCG), $(+)$-catechin and (-)-epicatechin, ferulic acid, and vanillin, possess the proper structural features to directly interfere with the proteins involved in the amyloid aggregation so as to inhibit their pathological assembly [26-33]. In this regard, a protein that has recently been used as a model system for characterizing the direct interference of polyphenols with proteins susceptible to amyloid formation is $\mathrm{k}$-casein from bovine milk, which is able to form amyloid fibrillar structures in vitro under physiological conditions $\left(37^{\circ} \mathrm{C}\right.$ and neutral $\mathrm{pH})[28,34,35]$.

This is the smallest of the caseins and is responsible for the steric stability of the casein micelles [36]. In native environments, $\mathrm{k}$-casein forms multimeric colloidal systems through several types of interactions, such as disulfide bonds, electrostatic, hydrogen bonds, and hydrophobic interactions [37-40]. Researchers observed that $\mathrm{k}$-casein, both in its native and reduced-carboxymethylated form, is able to form amyloid fibrils in vitro if incubated at $37{ }^{\circ} \mathrm{C}$ [41-44]. The aggregation in vivo is prevented by the activity of the other two caseins, $\beta$ - and $\alpha$ s1-casein, which are also naturally present in bovine milk $[43,44]$ and known for their chaperone-like activity [45-49]. When the chaperonesystem fails, $\mathrm{k}$-casein forms corpora amylacea in the bovine mammary glands and in milk [45]. Differently from a typical nucleation-polymerization scheme, the rate-limiting step involved in K-casein amyloid fibrillogenesis is not an initial nuclei formation but the dissociation of amyloidogenic monomers from the initial multimeric state $[41,42,50]$. This amyloid precursor has a native $\beta$-strand conformation with the proper structural features leading to fibrillar aggregation and it has the same biophysical features of the amyloid core formed by A $\beta$ peptide in Alzheimer's disease $[41,42,50]$. Similar to the A $\beta$ peptide, $\kappa$-casein is the archetype of an amyloidogenic protein belonging to the class of Intrinsically Disordered Proteins (IDPs) [51]. More importantly, native k-casein forms micelle-like complexes and studies demonstrated that aggregates with micellar properties could play a role in amyloid formation of several proteins [52-54]. Studying the effect of some selected compounds on amyloid aggregation of proteins forming micelles could help to individuate inhibitors with a specific role towards such micelle-like conformations also gaining insight into their mechanism of action. For all these reasons, bovine milk protein $\mathrm{k}$-casein was used to study the effect of specific polyphenols, many of which present in apples, on the amyloid fibril formation mechanism [28,34,35].

In this study, $\mathrm{k}$-casein was used as a protein model to investigate the effect of polyphenolic extracts from apple peels in the amyloid aggregation processes. The apple cultivar was Fuji grown in Sicily. While several studies concerned the effect on amyloids of individual polyphenols found in apples, only an experiment, carried out by thioflavin T (ThT) assay, focused on the ability of the whole polyphenolic extract obtained from apples to inhibit an amyloid aggregation process [31]. However, the molecular mechanism underlying this inhibitory action is far from understood. This is a critical point to evaluate the therapeutic potentiality of fruit and vegetable total phenolic extracts, already tested for important conditions regarding human health [55], in the field of amyloid diseases.

To the best of our knowledge, no study has been performed on extracts from a waste product, like apple peel, in the amyloid aggregation process. These investigations, aimed at agricultural and food industry waste valorization, offer important incentives in the recovery and reutilization of valuable materials, thus sustaining the eco-system health and circular economy strategies. In fact, the waste from apples used for commercial products, 
like jam, juice, and jelly, constitute about $30 \%$ of the original fruits. This large amount of organic residue seriously contributes to increasing air pollution [2].

Here, we investigated the influence of the apple peel polyphenol extracts on the amyloid assembly process of $\mathrm{k}$-casein by incubating them with the protein before thermally inducing fibrillization. We used light scattering (LS) and thioflavin T (ThT) fluorescence assay to monitor the effect of the extracts on the K-casein aggregation, and fibril formation kinetics. Using Congo red binding assay, circular dichroism (CD), and atomic force microscopy (AFM), we monitored the structural and morphological features of the $\mathrm{k}$-casein species formed in the presence of the apple peel polyphenols (APP).

Our results show that the APP extract inhibited, in a dose-dependent manner, kcasein amyloid fibril formation, and the structural reorganization that occurs during the protein assembly was inhibited in the presence of APP. The aggregates resulting from Kcasein incubation with APP under amyloid formation conditions were different in number and morphology.

\section{Results}

\subsection{Total Phenolic Content (TPC), Antioxidant Properties, and Phenolic Characterization of} Extracts from Apples Peels

As a prior step to the experiments, we conducted a quantitative determination of the apple peel extract phenolic compounds using the Folin-Ciocalteu method. The results are reported in Table 1 where the TPC is expressed as catechin equivalents. For comparison, in the same table, TPC values from the same apple variety other tissues (flesh and whole fruit) are also reported. The results show that the peel had a significantly higher TPC value over both the flesh and whole fruit.

Table 1. The peel, flesh, and whole Fuji apple total phenolic content evaluated by Folin-Ciocalteu and the antioxidant properties assessed by ORAC assay. ORAC = oxygen radical absorbance capacity; $\mathrm{TE}=$ Trolox equivalents; $\mathrm{FW}=100 \mathrm{~g}$ fresh weight; and $\mathrm{CTE}=$ catechin equivalents.

\begin{tabular}{ccc}
\hline Tissue & ORAC Value $(\boldsymbol{\mu m o l ~ T E} / \mathbf{g}$ FW) & TPC (mg CTE/100 g of FW) \\
\hline Peel & $118 \pm 5$ & $315 \pm 20$ \\
Flesh & $13 \pm 5$ & $42 \pm 5$ \\
Whole fruit & $22 \pm 7$ & $54 \pm 8$ \\
\hline
\end{tabular}

We also evaluated the antioxidant capacity of the three tissues (peel, whole, and flesh) by using an oxygen radical absorbance capacity (ORAC) assay (Table 1). The ORAC method uses a biologically relevant free radical source (peroxyl radical), which is the most prevalent free radical in human biology [56]. Therefore, ORAC results can be correlated to in vivo studies on the antioxidant activity shown by apple polyphenols [57-61].

As shown in the table, the antioxidant activity of the polyphenolic extract from apple peel was significantly more marked when compared to the other tissues of the fruit.

The polyphenolic profile of Fuji apple peel extract was studied using ultra-highperformance liquid chromatography with heated electrospray ionization coupled to mass spectrometry (UHPLC-HESI-MS) techniques, and seven phenolic compounds were identified (Supplementary Materials, Figure S1). In good agreement with the literature data [5], the qualitative profile showed vanillin, gentisic acid, sinapinic acid, ferulic acid, epicatechin, quercetin, and procyanidin A2.

\subsection{Ability of the APP Extract to Influence $\kappa$-Casein Fibrillogenesis and Disaggregate $\kappa$-casein Preformed Fibrils}

The effect of polyphenolic extracts from the apple peel on the kinetics of $k$-casein aggregation was analyzed by Thioflavin T (ThT) fluorescence assay. ThT is a fluorescent dye that is known to reliably detect the formation of amyloid fibrils due to the significant increase in its emission intensity upon binding to the linear array of $\beta$-strands $[62,63]$. 
We analyzed the effect of APP at the concentrations of 5, 10, 20, and $40 \mu \mathrm{g} / \mathrm{mL}$, after testing their toxicity on NHI-3T3 cells. This is an easy-to-handle cell line that immortalized spontaneously [64] and, for this reason, it is considered more representative of normal cells than a tumor cell line. Hence, NIH/3T3 is one of the most frequently used lines in material/cell interaction research, and it has been previously used for studying the toxic effect induced on cells by amyloid insults $[22,65,66]$.

The above-mentioned concentrations were not cytotoxic after $72 \mathrm{~h}$ of treatment as reported in Figure S2 (Supplementary Materials). Figure 1 shows the ThT signal during the fibrillization kinetics of $50 \mu \mathrm{M} \mathrm{K}$-casein incubated at $37^{\circ} \mathrm{C}$ in the absence and in the presence of different APP concentrations. In the absence of polyphenols, ThT from $\mathrm{k}$-casein exhibited an increase in fluorescence emission, which is indicative of amyloid formation. The absence of a lag phase in the kinetics profile is due to an aggregation mechanism in which the rate-limiting step is not the initial nuclei aggregation but the dissolution of native protein multimers with subsequent exposition to the solvent of buried amyloidogenic regions [41,42].

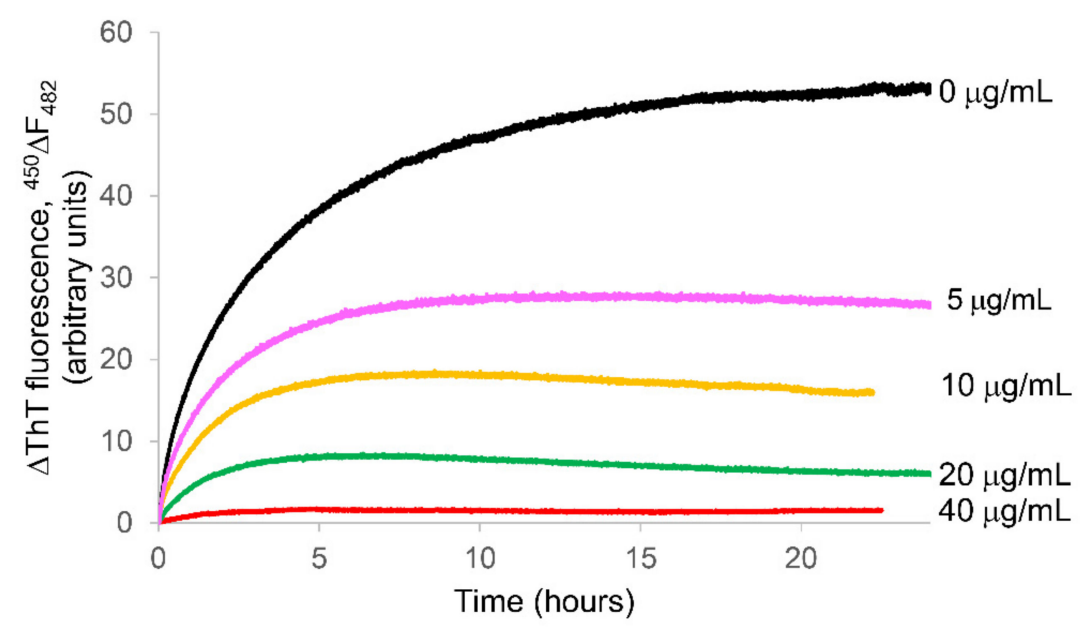

Figure 1. In situ real-time thioflavin $\mathrm{T}$ fluorescence assay for monitoring the aggregation kinetics of $50 \mu \mathrm{M}(\sim 1 \mathrm{mg} / \mathrm{mL}) \mathrm{K}$-casein incubated at $37^{\circ} \mathrm{C}$ in the absence (black) and in the presence of different APP concentrations: $5 \mu \mathrm{g} / \mathrm{mL}$ (pink), $10 \mu \mathrm{g} / \mathrm{mL}$ (yellow), $20 \mu \mathrm{g} / \mathrm{mL}$ (green), and $40 \mu \mathrm{g} / \mathrm{mL}$ (red).

In the presence of APP, both the aggregation rate and the fluorescence plateau, corresponding to the total amount of fibrils, were reduced in a concentration dependent manner (Figure 1).

As the next step, we verified that, in addition to inhibiting protein aggregation, APP were also able to disaggregate preformed $\mathrm{k}$-casein amyloid structures. To do this, we added APP at $40 \mu \mathrm{g} / \mathrm{mL}$ to the $50 \mu \mathrm{M} \mathrm{k}$-casein sample taken at the end of the aggregation kinetics (after about $24 \mathrm{~h}$ at $37^{\circ} \mathrm{C}$ ) and followed the dye fluorescence for the next $8 \mathrm{~h}$ at $37^{\circ} \mathrm{C}$. After an initial phase taken for the system to achieve the thermal equilibration, the fluorescence did not vary in time (Figure 2), thus revealing that, while APP were able to inhibit protein aggregation, they could not disrupt already formed amyloid assemblies.

This experiment was also useful in order to exclude the occurrence of potential interference between the dye and APP. Caution is recommended in the use of thioflavin T assay when probing anti-amyloidogenic compounds that, even if not spectroscopically active at ThT wavelengths, like the APP under analysis (data not shown), can interfere with the dye fluorescence causing a bias affecting the experimental data interpretation [35,67]. Our experiment showed that APP did not cause ThT fluorescence reduction by interfering with the dye in a time of about $8 \mathrm{~h}$, thus excluding the occurring of fluorescence quenching, in this time, by the introduction of phenols. 


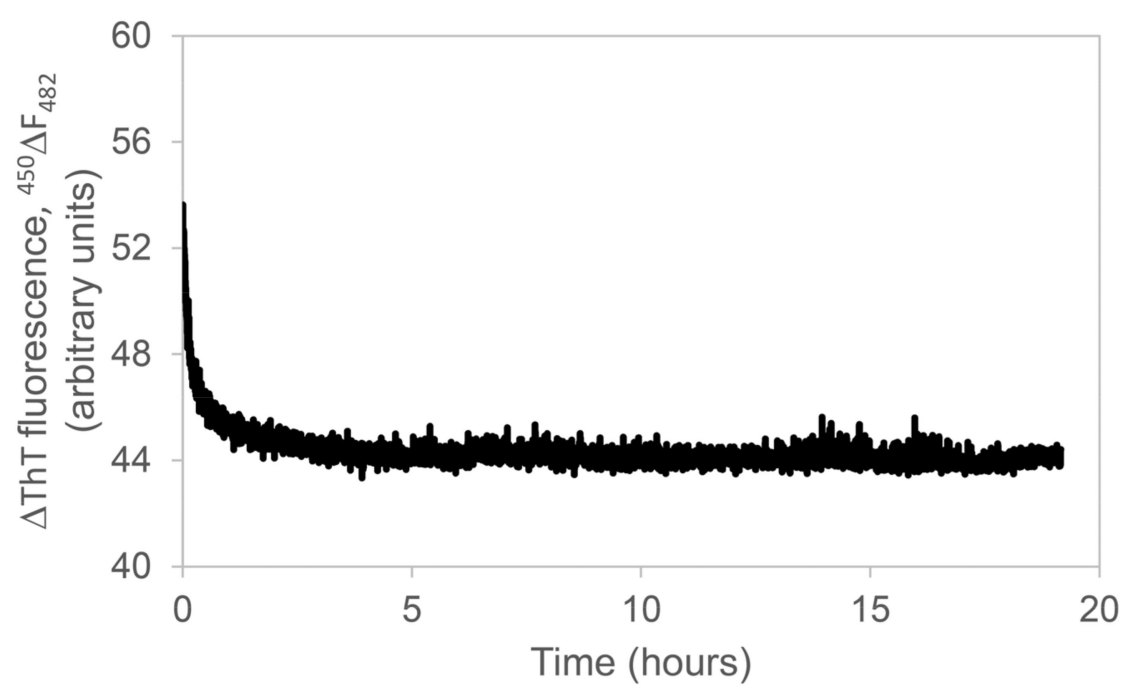

Figure 2. Fluorescence of Thioflavin $\mathrm{T}$ as a function of time after the addition of $40 \mu \mathrm{g} / \mathrm{mL}$ APP to $50 \mu \mathrm{M}(\sim 1 \mathrm{mg} / \mathrm{mL}) \mathrm{K}$-casein species formed after $24 \mathrm{~h}$ incubation at $37^{\circ} \mathrm{C}$.

\section{3. $\beta$-Sheet-Amyloid Formation Assessed by the Congo Red Binding Assay}

We used other experimental tools to confirm the inhibitory APP effect found by the ThT assay. First, we used the absorptive dye, Congo red (CR), which has been demonstrated as a viable alternative to ThT in the case of potential interference with exogenous compounds precisely tested with $\mathrm{k}$-casein [35]. CR allows the detection of the presence of amyloid $\beta$-pleated sheets, because, when bound to $\beta$-sheet-rich amyloid fibrils, the CR molecules adopt a specific orientation with their long axis lying parallel to the fibril axis. This causes a molecular CR torsional restriction that induces a characteristic increase in absorption and a red shift in the absorption maximum from 490 to $540 \mathrm{~nm}$ [68]. To further investigate inside the $\beta$-sheet-amyloid formation in $\mathrm{k}$-casein aggregates and evaluate the effect of APP on $\kappa$-casein assembly process, we added $20 \mu \mathrm{M} \mathrm{CR}$ to aliquots of $50 \mu \mathrm{M}$ fresh native $\mathrm{k}$-casein and the protein after $24 \mathrm{~h}$ of incubation at $37^{\circ} \mathrm{C}$. The experiment was performed on samples incubated both in the presence and absence of APP at $40 \mu \mathrm{g} / \mathrm{mL}$. After the dye addition, the $\mathrm{CR}$ absorption band was recorded immediately. In Figure 3a, the spectra of CR alone, $\mathrm{CR}$ in the presence of fresh native $\mathrm{k}$-casein, and CR in the presence of $\mathrm{k}$-casein after $24 \mathrm{~h}$ of incubation at $37^{\circ} \mathrm{C}$ are presented. In the presence of fresh native $\mathrm{k}$-casein, the $\mathrm{CR}$ spectrum showed, in comparison to free dye, a slight shift from 500 to $510 \mathrm{~nm}$ likely due to the dye binding to protein initial micelles. However, a more marked change occurred when CR was incubated with the $\mathrm{k}$-casein preformed structure formed after $24 \mathrm{~h}$ at $37^{\circ} \mathrm{C}$. A shoulder at $540 \mathrm{~nm}$ appeared, indicative of CR binding to $\beta$-sheet-rich amyloid fibrils [68]. In the presence of polyphenols, no significant change in the absorbance maximum wavelength was observed between the spectra of $\mathrm{CR}$ added to the native $\mathrm{k}$-casein $+\mathrm{APP}$ and the same sample taken after $24 \mathrm{~h}$ incubation at $37^{\circ} \mathrm{C}$ (Figure 3b). This further confirms the APP inhibitory action toward amyloid formation. 


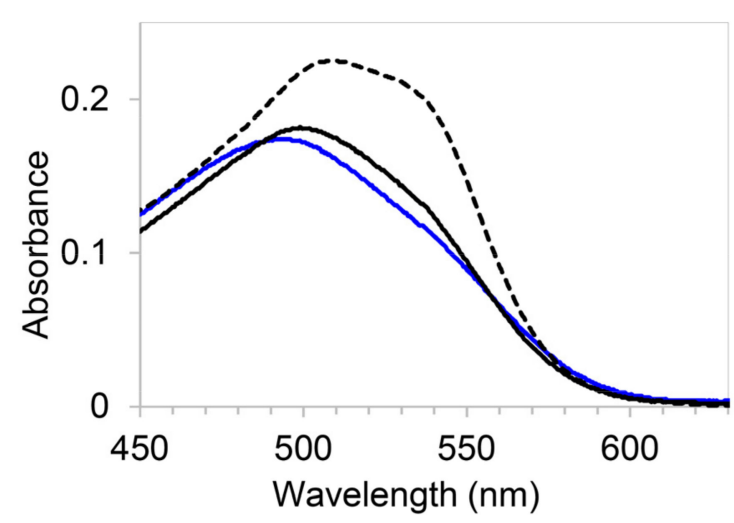

(a)

(b)

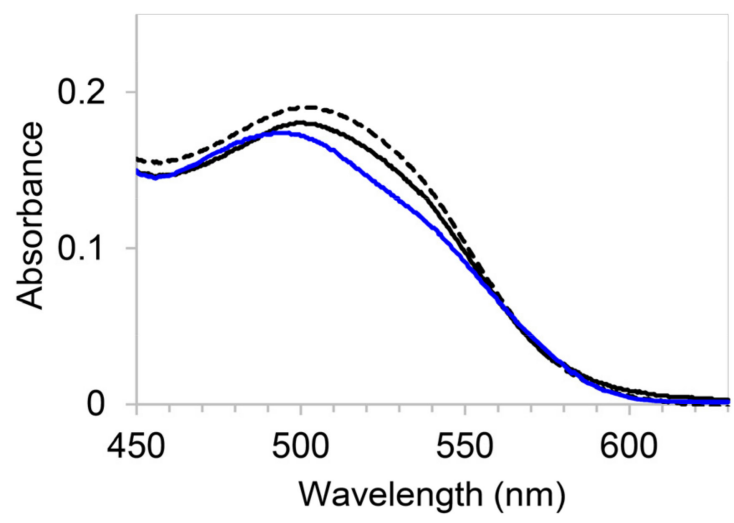

Figure 3. (a) Absorption spectra of $20 \mu \mathrm{M}$ Congo red (blue), Congo red with $50 \mu \mathrm{M}$ fresh native $\mathrm{k}$-casein (solid black line), and with $50 \mu \mathrm{M} \mathrm{k}$-casein incubated for $24 \mathrm{~h}$ at $37^{\circ} \mathrm{C}$ (dashed black line). (b) Absorption spectra of $20 \mu \mathrm{M}$ Congo red $+40 \mu \mathrm{g} / \mathrm{mL}$ APP (blue), CR with $50 \mu \mathrm{M}$ k-casein $+40 \mu \mathrm{g} / \mathrm{mL}$ APP before (solid black line), and after incubation $24 \mathrm{~h}$ at $37^{\circ} \mathrm{C}$ (dashed lack line).

\subsection{Apple Peel Polyphenols Influence on $\kappa$-Casein Secondary Structure}

We used circular dichroism (CD) to monitor the secondary structure variation of $k$ casein incubated under amyloid aggregation conditions in the absence and in the presence of different APP concentrations. In Figure $4 \mathrm{a}$, the $\mathrm{k}$-casein spectra at the beginning of the aggregation process, which starts with thermal incubation at $37^{\circ} \mathrm{C}\left(\mathrm{t}_{0}\right)$, and after about $24 \mathrm{~h}\left(\mathrm{t}_{\text {end }}\right)$, corresponding to the plateau in protein fibrillogenesis kinetics (Figure 1), are reported. We found that, similar to what was reported by Farrell et al. [40], the protein during amyloid formation underwent a conformational transition with two spectral changes, one at $200 \mathrm{~nm}$, and the other, more marked, at around $220 \mathrm{~nm}$. As shown by electron microscopy experiments, these spectral changes are associated, by Farrell et al., with the formation of structures with fibrillar morphology. The fibrillization of $\mathrm{k}$-casein starts from the dissociation from the oligomeric state, which is considered the rate limiting step in the protein fibril formation [41,42]. The dissociated species, characterized by a significant percentage of $\beta$-native structure, would be the amyloidogenic precursor of fibrillar assembly through a $\beta$-sheet stacking that would not dramatically increase the total $\beta$-structure content but would be responsible for variations in the distribution of secondary $\beta$-strand and turn elements, thus determining the shape changes in the CD spectrum. These variations were not detectable when the protein was incubated with extracts from apple peel at $40 \mu \mathrm{g} / \mathrm{mL}$ polyphenolic content (Figure $4 \mathrm{~b}$ ), which was the most effective in preventing ThT fluorescence increase. The two spectra, at the beginning $\left(\mathrm{t}_{\text {start }}\right)$ and after $24 \mathrm{~h}\left(\mathrm{t}_{\mathrm{end}}\right)$ of incubation, almost overlap. At the APP concentrations' intermediate range $(5,10$, and $20 \mu \mathrm{g} / \mathrm{mL}$ ), the higher the polyphenol content (Supplementary Materials, Figure S3), the more evident the changes in the spectra between that recorded at initial 
time $t_{\text {start }}$ and after $24 \mathrm{~h}\left(\mathrm{t}_{\text {end }}\right)$ of incubation. To better visualize these results, we reported, in Figure $4 c$, the difference squared between the $k$-casein spectra recorded at $t_{\text {start }}$ and $t_{\text {end }}$ in the wavelength region around $222 \mathrm{~nm}$. As the figure shows, the extract from apple peel was able, in a concentration-dependent manner, to reduce the spectra changes sensitive to the conformational transitions that accompany the $\mathrm{k}$-casein amyloid formation.
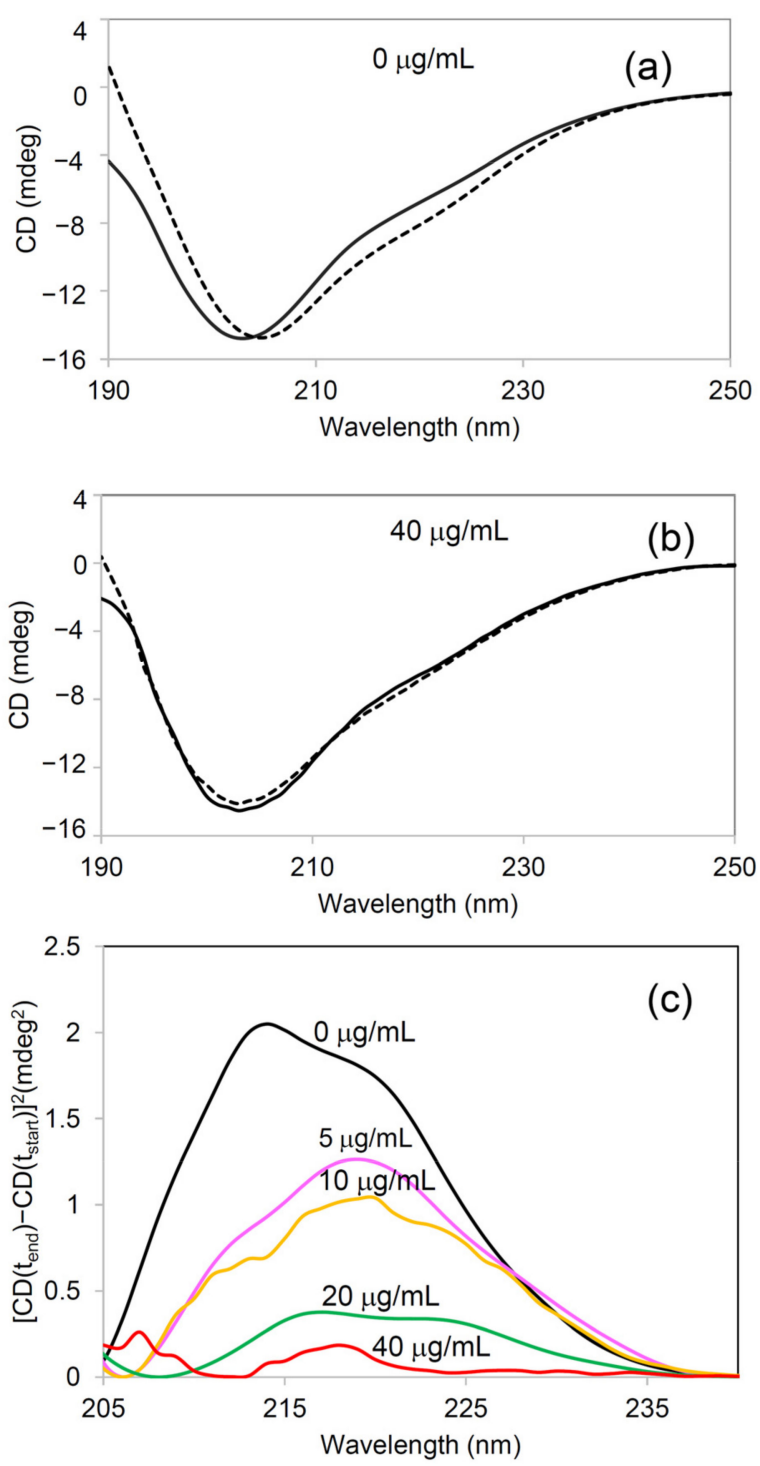

Figure 4. Circular dichroism (CD) spectra of $50 \mu \mathrm{M} \kappa$-casein at the beginning $\left(\mathrm{t}_{\text {start }}\right)$ of the amyloid aggregation process (solid black) and after $24 \mathrm{~h}\left(\mathrm{t}_{\mathrm{end}}\right)$ of incubation at $37{ }^{\circ} \mathrm{C}$ (dashed black) in the absence (a) and presence of $40 \mu \mathrm{g} / \mathrm{mL}$ of APP (b). (c) Squared difference between the spectrum at $t_{\text {start }}$ and $t_{\text {end }}$ in the absence (black) or the presence of different APP concentrations: $5 \mu \mathrm{g} / \mathrm{mL}$ (pink), $10 \mu \mathrm{g} / \mathrm{mL}$ (yellow), $20 \mu \mathrm{g} / \mathrm{mL}$ (green), and $40 \mu \mathrm{g} / \mathrm{mL}$ (red).

\subsection{Apple Peel Polyphenols Influence on $\kappa$-Casein Aggregation Monitored by Light Scattering}

To further evaluate the $\mathrm{k}$-casein aggregation process, we carried out static and dynamic light scattering measurements of $\mathrm{k}$-casein incubated at $37{ }^{\circ} \mathrm{C}$ in the absence and in the presence of APP at the concentration of $40 \mu \mathrm{g} / \mathrm{mL}$ that, as revealed by ThT assay and CD measurements, was the most effective concentration among the tested ones in inhibiting amyloid formation. The light-scattering intensity depends on the molecular mass of a species in solution and, therefore, is a suitable technique to monitor the aggregation 
process. $\mathrm{k}$-casein is initially in an oligomeric micelle-like state, and this is reflected in the light-scattering intensity value that is detected at the beginning of the process.

When $\mathrm{K}$-casein was incubated at $37^{\circ} \mathrm{C}$, an increase in the intensity scattered from the particles in solution occurred in time. The static scattered intensity, in particular, switched from $540 \mathrm{kcps}$ to $700 \mathrm{kcps}$, from the beginning to the end of the process, with an increase of $30 \%$ indicating the occurrence of an aggregation process (Figure $5 \mathrm{a}$ ). By the cumulant analysis of the intensity autocorrelation function generated by LS in dynamic modality, a correspondent increase in the average hydrodynamic diameter of species in solution from 100 to $110 \mathrm{~nm}$ was also found (Figure $5 \mathrm{~b}$ ).

(a)

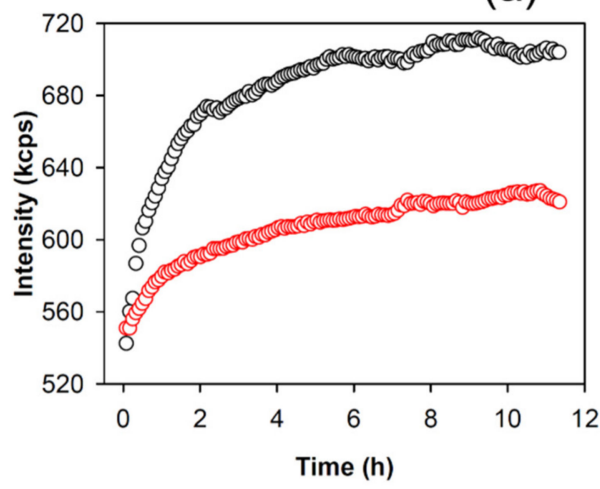

(b)

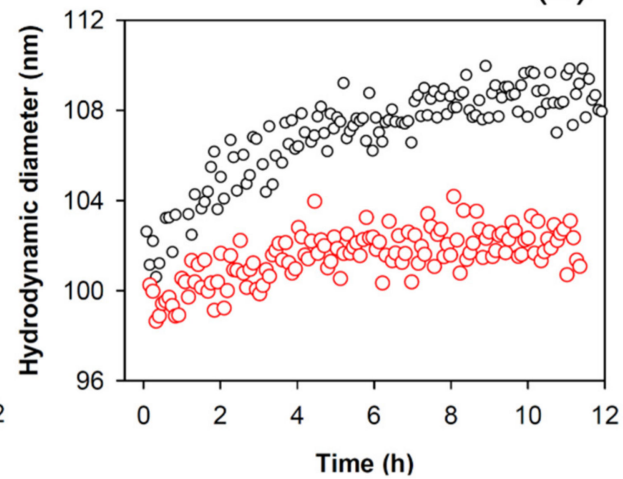

Figure 5. (a) The time course of the light scattered intensity (measured as kilo count per seconds (kcps), referring to the average number of photons per second arriving at the detector) from $\mathrm{k}$-casein $\left(50 \mu \mathrm{M}=1 \mathrm{mg} / \mathrm{mL}\right.$ ) incubated at $37{ }^{\circ} \mathrm{C}$ in the absence (black circles) and presence of $40 \mu \mathrm{g} / \mathrm{mL}$ of apple peel polyphenols (red circles). (b) Time-course of the hydrodynamic diameters of $\mathrm{k}$-casein ( $50 \mu \mathrm{M}=1 \mathrm{mg} / \mathrm{mL}$ ) incubated in the absence (black circles) and presence of $40 \mu \mathrm{g} / \mathrm{mL}$ of apple polyphenols (red circles) obtained from the cumulant analysis of the intensity autocorrelation function.

When $\mathrm{k}$-casein was incubated with $40 \mu \mathrm{g} / \mathrm{mL}$ of APP extract, the increase in the scattered intensity was significantly reduced (Figure 5a). It switched from 540 to $610 \mathrm{kcps}$ with an increase of only $13 \%$ compared to the $\mathrm{k}$-casein alone condition. A slight variation in the average hydrodynamic diameter of species in solution was observed as it remained at about $100 \mathrm{~nm}$ (Figure 5b).

\subsection{Morphology of $\kappa$-Casein Aggregates Incubated with Apple Peel Polyphenols}

To analyze the morphology of the $\mathrm{k}$-casein species formed at the end of kinetics in the presence or absence of $40 \mu \mathrm{g} / \mathrm{mL}$ APP, AFM imaging was applied. When $\mathrm{k}$-casein was incubated alone, fibrillar rod-shaped structures with average height of $5.13 \mathrm{~nm}$ and length of $100 \mathrm{~nm}$ (Figure 6a) were observed. According to the other techniques, when $\mathrm{k}$-casein was incubated in the presence of APP extract $(40 \mu \mathrm{g} / \mathrm{mL}$ ) (Figure $6 \mathrm{~b})$, the number of fibers and amyloid aggregates was found to be significantly reduced (Figure $6 \mathrm{c}$ ). 
(a)

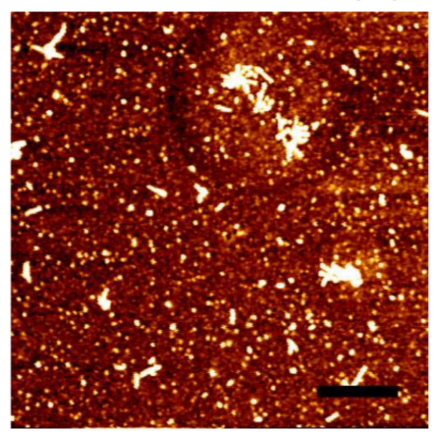

(b)

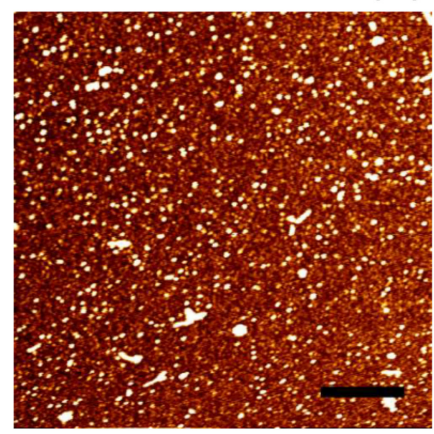

(c)

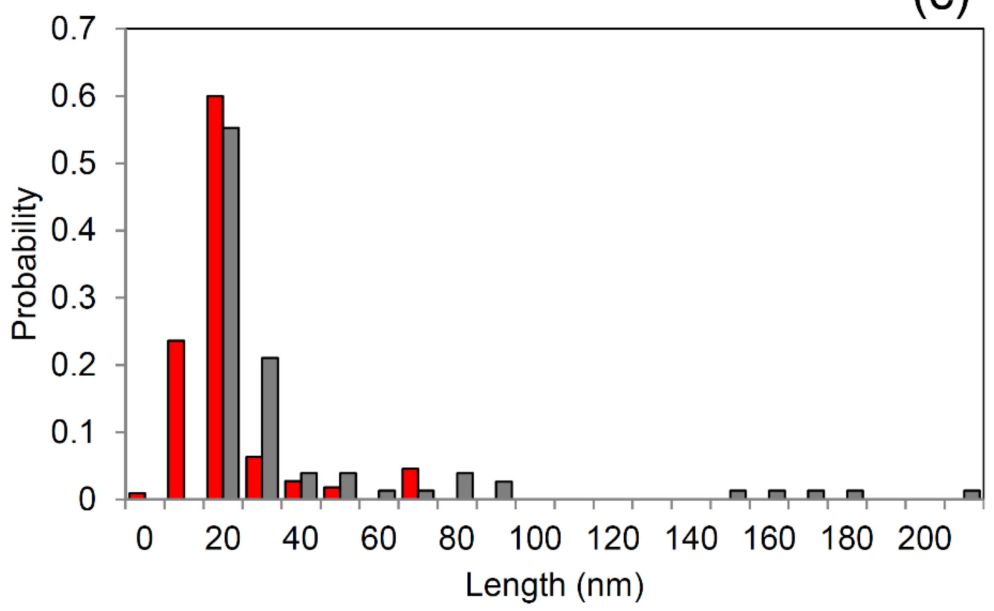

Figure 6. The morphology of $\mathrm{k}$-casein species formed in the absence and presence of polyphenols (a) $\mathrm{k}$ casein aggregates $(50 \mu \mathrm{M})$ formed at the end of the aggregation kinetics $(12 \mathrm{~h})$. (b) $\mathrm{K}$-casein aggregates $(50 \mu \mathrm{M})$ formed after $12 \mathrm{~h}$ in the presence of $40 \mu \mathrm{g} / \mathrm{mL}$ apple polyphenols. Scale bar $=400 \mathrm{~nm}$ and z-range $=5.3 \mathrm{~nm}$. (c) Distributions of the lengths for the sample populations in the absence (grey) and presence of polyphenols (red).

\subsection{Apple Peel Polyphenols Effect on A $\beta_{1-42}$ Peptide Aggregation Monitored by Light Scattering}

To add value to the results thus far obtained, we concluded our study by obtaining information on APP action on the amyloid aggregation process of a protein that, differently from $\mathrm{K}$-casein, is involved in a severe and common disease for human health. Hence, we tested the APP effect on the A $\beta_{1-42}$ peptide involved in Alzheimer' Disease by using the free-dye light scattering technique. It is known that heating from 0 to $37{ }^{\circ} \mathrm{C}$ induces, in the $A \beta_{1-42}$ peptide, a conversion from coil to beta-strand structures typical of amyloid formation [69]. As shown in Figure $7 \mathrm{a}$, when the $\mathrm{A} \beta_{1-42}$ peptide is incubated at $37^{\circ} \mathrm{C}$ in the presence of APP, the increase found in the light scattered for the $A \beta_{1-42}$ peptide alone, and indicative of the aggregation process, was strongly reduced.

However, as shown by the analysis of the hydrodynamic radii, also in this case, in the presence of $A P P, A \beta_{1-42}$ forms aggregated species, although lower in size with respect to the control (Figure $7 \mathrm{~b}$ ). Further studies should aim to better understand the structural and pathological features of the $A \beta_{1-42}$ peptide species resulting from the APP; however, this is out of the objectives of the present study. We just want to highlight the importance of considering the synergic action of phenols from natural sources in the amyloid aggregation mechanisms at the basis of dangerous conditions for human health. 
(a)

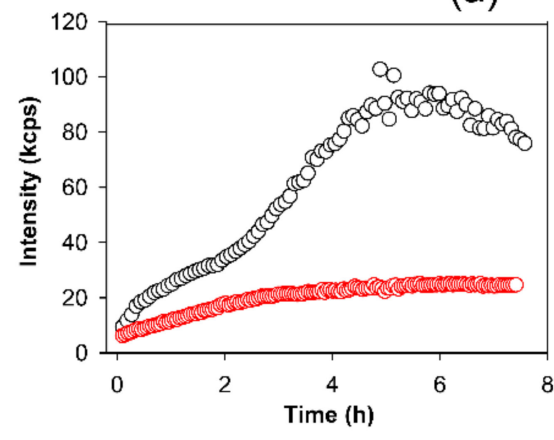

(b)

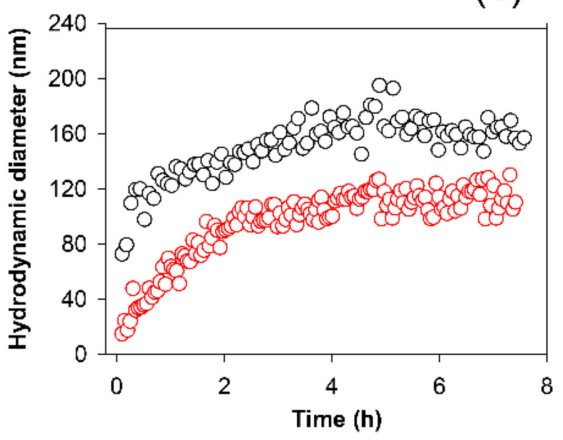

Figure 7. (a) Time-course of the light scattered intensity (measured as kilo count per seconds (kcps), referring to the average number of photons per second arriving at the detector) from $50 \mu \mathrm{M} \mathrm{A} \beta_{1-42}$ incubated at $37^{\circ} \mathrm{C}$ in the absence (black circles) and presence of $40 \mu \mathrm{g} / \mathrm{mL}$ of apple peel polyphenols (red circles). (b) Time-course of the hydrodynamic diameters of $A \beta_{1-42}$ incubated in the absence (black circles) and presence of $40 \mu \mathrm{g} / \mathrm{mL}$ of apple polyphenols (red circles) obtained from the cumulant analysis of the intensity autocorrelation function.

\section{Discussion}

The aim of our study was to gain insight into the ability of polyphenolic extracts to prevent the amyloid aggregation of the $\mathrm{k}$-casein, used as amyloidogenic protein model. The extracts were from apple peels, which are normally disposed of as waste in agriculture and the food industry. Several studies reported the ability of specific single polyphenols to inhibit both oxidative stress and protein aggregation associated with neurodegenerative diseases. However, few studies focused on the direct action on amyloid aggregation pathways exerted by the whole polyphenolic extract from fruit tissues generally considered as waste.

Research has shown that apples are a great source of bioactive compounds [5] with marked antioxidant activity and antiproliferative activity [5-7], and we demonstrated that the peels from the Fuji apples under study presented higher phenolic contents and more marked antioxidant activity with respect to the flesh and whole fruit (Table 1). The polyphenolic profile of Fuji apple peel extracts was studied using UHPLC-HESI-MS techniques, and seven phenolic compounds were identified (Supplementary Materials, Figure S1). In agreement with the literature data, a qualitative profile found vanillin, gentisic acid, sinapinic acid, ferulic acid, epicatechin, quercetin, and procyanidin A2, many of which have been revealed to be effective in preventing protein amyloid aggregation when singly tested [26-33], but they have never been tested in a natural phenolic pool.

To monitor the APP effect on amyloid formation mechanisms, we used $\mathrm{k}$-casein from bovine milk, a suitable model protein to study the aggregation processes in vitro. First, $\mathrm{k}$-casein forms fibrils at $\mathrm{pH}$ and temperature conditions $\left(\mathrm{pH} 7.0\right.$ and $37^{\circ} \mathrm{C}$ ) that well reproduce the physiological cell environment [41,42]. In addition, according to the Ecroyd model, a $\mathrm{k}$-casein monomer contributes more than one $\beta$-strand to the fibril structure, in a similar manner to that shown for the amyloid A $\beta$ peptide involved in AD [70]. Similar to the peptides and proteins involved in several amyloid diseases (e.g., Alzheimer's and Parkinson's disease), $\mathrm{k}$-casein adopts an essentially unstructured conformation in its normal biological state (i.e., it belongs to the class of Intrinsically Disordered Proteins (IDPs)) [43,51]. More importantly, $\mathrm{k}$-casein forms micelles, and several studies hypothesized the crucial role of potential intermediate micellar conformations in amyloid fibrillogenesis [52-54].

Here, we show that APP at concentrations not toxic for cells (Figure S2) significantly inhibited $\mathrm{k}$-casein amyloid fibril formation in a concentration-dependent manner. Both the rate and the plateau of the protein fibrillogenesis kinetics profile were reduced in the presence of APP, and the effect was more marked at increasing concentrations of incubated polyphenols (Figure 1). At the highest phenol concentration tested $(40 \mu \mathrm{g} / \mathrm{mL}$ ), the thioflavin $\mathrm{T}$ increase appeared to be totally inhibited. The marked increase in ThT 
fluorescence results from the selective immobilization in the conformational ensemble of the dye. When free, the benzylamine and benzathiole rings of ThT can rotate with no constraints about their shared carbon-carbon bond. This rotation rapidly quenches the excited states generated by photon excitation causing low fluorescence emission for free ThT. Instead, in the presence of amyloid fibrils, the rings are sterically immobilized, and this preserves the excited state, resulting in a high fluorescence quantum yield. Therefore, ThT can be considered as a "molecular rotor" [71]. To exclude the potentially occurring interactions of polyphenols-ThT [35,67], we verified that fluorescence of the dye was not influenced by APP. In order to do this, we added $40 \mu \mathrm{g} / \mathrm{mL}$ APP to a sample of preformed $\mathrm{K}$-casein fibrils and ThT and verified that the dye fluorescence, enhanced by the presence of fibrillar structures, did not change in time (Figure 2), thus excluding the occurring of fluorescence quenching by the introduction of phenols.

Furthermore, we also used alternative dyes and dye-free tools to confirm the APP inhibitory properties. First, we confirmed the $\beta$-sheet formation in $\kappa$-casein incubated at $37{ }^{\circ} \mathrm{C}$ by using Congo red (CR) whose spectral shift assay is an alternative to ThT fluorescence for quantifying amyloid fibril formation [35]. The spectral shift present when $\mathrm{CR}$ is added to $\mathrm{K}$-casein after $24 \mathrm{~h}$ at $37{ }^{\circ} \mathrm{C}$ is absent when the dye is added to the protein incubated, under the same conditions, with APP (Figure 3). Then, we used circular dichroism to evaluate the APP ability to prevent the secondary structure variation that accompanies $\mathrm{K}$-casein amyloid formation. In agreement with thioflavin $\mathrm{T}$ experiments, this secondary structure variation was lower for higher APP concentrations, and the $\mathrm{k}$-casein spectrum registered after $24 \mathrm{~h}$ of incubation at $37^{\circ} \mathrm{C}$ in the presence of APP at $40 \mu \mathrm{g} / \mathrm{mL}$ did not present significant changes in respect to the $\mathrm{k}$-casein at the initial state (Figure 4).

When $\mathrm{k}$-casein was incubated with APP at $40 \mu \mathrm{g} / \mathrm{mL}$, the light scattered intensity variation from the sample was significantly reduced when compared to the control sample (Figure 5a) with very little variation in the average hydrodynamic diameter of species in solution observed over time (Figure $5 b$ ). The presence of aggregated species formed from $\mathrm{K}$-casein in the presence of $40 \mu \mathrm{g} / \mathrm{mL} \mathrm{APP}$, even if lower in size, morphologically different, and reduced in number with respect to the control, was also observed by AFM (Figure 6).

This is a very critical point because, as well established, amyloid oligomers smaller in size than the mature fibrillary structures are greatly more toxic than fibrils, due to a greater number of open active ends and their ability to diffuse in tissues [20-22]. However, the $\kappa$-casein aggregates formed in the presence of APP do not possess the amyloid cross- $\beta$ spine structure that, in restricting the thioflavin rings rotation, determines a high fluorescence quantum yield. CD experiments further prove that these aggregates are prevented from forming the $\beta$-sheet stacking, which is responsible for the secondary structure content variation observed during $\mathrm{K}$-casein amyloid formation.

According to the model proposed by Ecroyd et al. [41,42], the $\mathrm{k}$-casein dissociation from the oligomeric state is the rate-limiting step in $\mathrm{k}$-casein fibril formation. The dissociated species, characterized by a significant percentage of $\beta$-native structure, would be an amyloidogenic precursor of fibrillar assembly through $\beta$-sheet stacking that would not dramatically increase the total $\beta$-structure content but would be responsible for variations in the distribution of secondary $\beta$-strands and turn elements. We hypothesize that this reorganization, leading to $\beta$-sheet packing occurring inside the first oligomers, is prevented by the interference with polyphenols.

Research reported that polyphenols are capable of directly interacting with the protein amyloidogenic core through specific structural constraints and aromatic interactions between the phenolic compounds and aromatic residues in the amyloidogenic sequence. The packing in $\mathrm{K}$-casein amyloid formation would involve residues from position to 20 to 68 that contain not-stranded, highly hydrophobic $\beta$-sheets (from 20 to 25, 29 to 34, 39 to 45, and 49 to 55) connected by $\gamma$ or $\beta$-turns [50]. These segments belong to a tyrosine-rich region (Figure 8), which, therefore, is highly susceptible to aromatic interactions with APP that we believe to occur before potential further packing leading to the amyloid core formation. 


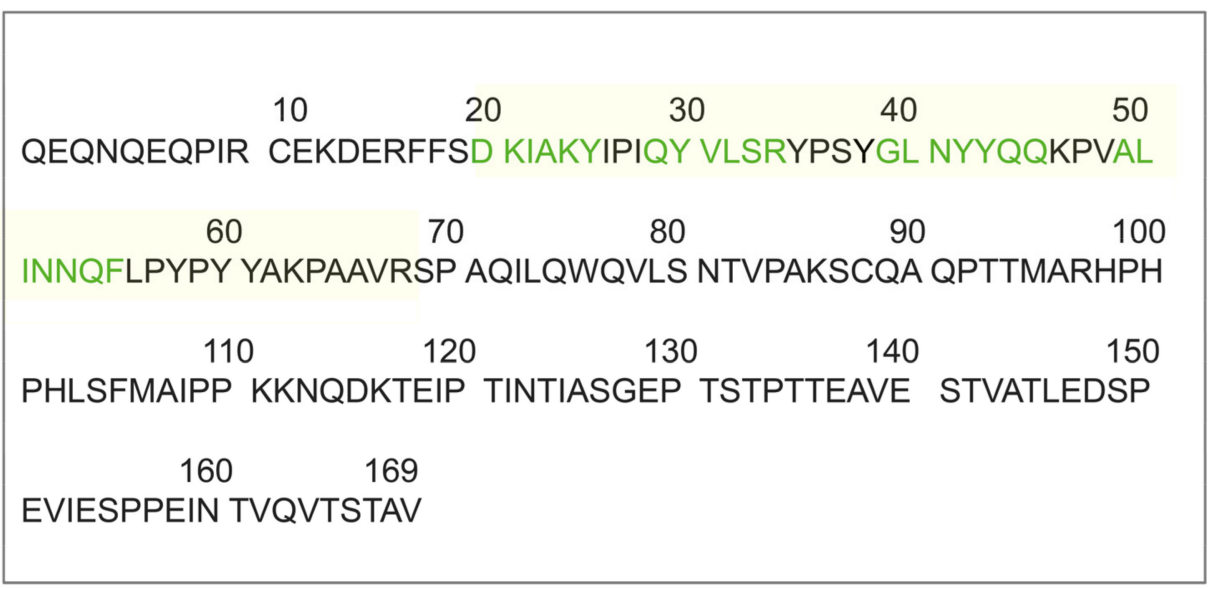

Figure 8. The amino acid sequence (signal sequence-deprived) of $\mathrm{k}$-casein from bovine milk (UniProtKB-P02668). The region involved in protein packing during amyloid formation is in light yellow. Residues belonging to native $\beta$-sheets are in green.

The aromatic interactions could be at the basis of the preventive action exerted by tannin and (-)-epigallocatechin-3-Gallate (EGCG) against k-casein aggregation and, in general, for polyphenol inhibitors in amyloid aggregation through direct interactions with the proteins involved [28,34,35].

Our studies also revealed that APP did not show disrupter activity on k-casein fibrils. This could be indicative of fibrillary stiffness or most likely, since only few protein segments are involved in the formation of the cross- $\beta$-sheet fibrillar structure, the remainder of the molecule could prevent the APP from reaching the fibril core, thus, impeding the formation of the preferential noncovalent interactions responsible for the dissolution of the fibrils.

\section{Materials and Methods}

\subsection{Materials}

K-casein (UniProtKB-P02668) from bovine milk and all the reagents and chemicals were purchased from Sigma-Aldrich (St. Louis, MO, USA) except when mentioned specifically.

\subsection{Plant Materials}

Fuji apples were harvested at commercial maturity from "Scannale s.r.l.", an organic farm located in Caltavuturo ( $37^{\circ} 49^{\prime} \mathrm{N}$ and $850 \mathrm{~m}$ a.s.l.) (Sicily, Italy). Fruits were harvested at optimum maturity assessed by the starch iodine test (starch index value of 6; [72]). The apples were washed and stored at $4{ }^{\circ} \mathrm{C}$.

Weight, longitudinal (LD) and transverse (TD) diameters, and flesh firmness of apples were detected. The fruits were individually weighted with a precision balance. LD and TD were measured with a digital caliper. The flesh firmness was measured on half of fruits with a penetrometer with a cylindrical $8 \mathrm{~mm}$ head (EFFEGI texture analyzer). Chemical parameters such as titratable acidity (TA), $\mathrm{pH}$, and soluble solid content (SSC) were also detected. TA was performed by titrating an aliquot of $5 \mathrm{~mL}$ of filtered apple juice with a solution of $\mathrm{NaOH} 0.1 \mathrm{~N}$ and expressed in percentage of malic acid. The SSC were measured with digital refractometer (Atago) and reported as ${ }^{\circ}$ Brix. Ripe Index (RI) was also calculated as the ratio between SSC, expressed in ${ }^{\circ}$ Brix, and TA, and expressed in percentage $(\%)$. Physical parameters data: weight $=(158.76 \pm 0.45) \mathrm{g} ; \mathrm{LD}=(60.10 \pm 0.29)$ $\mathrm{mm} ; \mathrm{TD}=(66.70 \pm 0.17) \mathrm{mm}$; firmness $=(4.46 \pm 0.45) \mathrm{Kg} / \mathrm{cm}^{2}$. Chemical parameters data: $\mathrm{pH}=3.9 \pm 0.1 ; \mathrm{TA}=(0.30 \pm 0.03) \%$ malic ac.; $\mathrm{SSC}=18.52 \pm 0.10^{\circ}$ Brix; $\mathrm{RI}=61.73 \pm 0.83$. All parameters were obtained by a mean of five measures. Thirty Fuji apples free of defects were selected and peeled ( 1 mm thickness) then the apple peels were pooled and frozen in liquid nitrogen and stored at $-80^{\circ} \mathrm{C}$ until analysis. 


\subsection{APP Extraction, Phenolic Content Determination and Antioxidant Properties Evaluation 4.3.1. Polyphenol Extraction}

Polyphenols were extracted by a peel pool of at least thirty Fuji apples according to the method described by Ceymann et al. [73], with some modifications. Frozen peels were ground to fine powder by using a grinder and then the polyphenolic extraction was carried out. Briefly, an aliquot of the powder $(2.50 \mathrm{~g})$ was mixed with $50 \mathrm{~mL}$ of methanol containing $1 \%$ formic acid $(v / v)$, homogenized for $15 \mathrm{~min}$, and centrifuged at 10,000 rpm for $10 \mathrm{~min}$. The supernatant was collected and filtered through $0.45 \mu \mathrm{m}$ nylon filters. The polyphenols' extraction was repeated three times. The same protocol was used to extract polyphenols from whole and flesh Fuji apple and compare the results with those obtained for the peel. For toxicity and k-casein experiments, the extraction solvent was removed by rotatory evaporator at $30{ }^{\circ} \mathrm{C}$ and the concentrated peel polyphenolic extract was dissolved in water, aliquoted, and kept at $-20^{\circ} \mathrm{C}$ until analysis, avoiding direct contact with light and oxygen.

\subsubsection{Total Polyphenol Content (TPC) by Folin-Ciocalteu}

The TPC analysis was performed following the polyphenols extraction by the FolinCiocalteu method in Ceymann et al. [73] with slight modifications. Two microliters of the Folin-Ciocalteu reagent and $2 \mathrm{~mL}$ of distilled water were automatically pipetted to $0.2 \mathrm{~mL}$ of the methanolic extract. After $1 \mathrm{~min}, 0.8 \mathrm{~mL}$ sodium carbonate solution (20\%) and $0.8 \mathrm{~mL}$ distilled water were added, thoroughly mixed, and incubated for $30 \mathrm{~min}$ at $37^{\circ} \mathrm{C}$. Absorption was measured automatically at $750 \mathrm{~nm}$. Total polyphenolic content was calculated with the external standard catechin calibration curve and expressed as $\mathrm{mg}$ catechin equivalents (CTE) per $100 \mathrm{~g}$ fresh weight (FW). The test was carried out in triplicate.

\subsubsection{Identification of Polyphenols by UHPLC-HESI-MS}

Identification of polyphenols in Fuji apple peel extract was based on a reported procedure [74,75]. Phenolic compounds were identified by ultra-high-performance liquid chromatography, heated electrospray coupled with high-resolution mass spectrometry (UHPLC-HESI-MS) analysis using a quadrupole Orbitrap mass spectrometer (Thermo Fisher Scientific, Bremen, Germany). UHPLC analysis was performed using a Dionex Ultimate 3000 System (Dionex Softron GmbH, Germering, Germany) equipped with an auto sampler controlled by Chromeleon 7.2 Software (Thermo Fisher Scientific, Bremen, Germany). The column was a Phenomenex Luna C18(2) $50 \times 1 \mathrm{~mm}$, packed with coreshell particles of $2.5 \mu \mathrm{m}$. The flow rate was set at $50 \mu \mathrm{L} \mathrm{min}{ }^{-1}$ at $20{ }^{\circ} \mathrm{C}$ and the total chromatographic analysis time was $52 \mathrm{~min}$. The eluent $\mathrm{A}$ was water with $0.1 \%$ formic acid $(v / v) \mathrm{pH} 3.2$, and eluent $\mathrm{B}$ was acetonitrile with $0.1 \%$ formic acid $(v / v)$. The elution gradient program was 0-5 min 10\% B; 5-45 min linear increase to $99 \%$ B, $45-50$ min $10 \%$ B coming back to the initial conditions until full stabilization. The MS detection was conducted in two acquisition modes: full scan (negative ion mode) and targeted selected ion monitoring. For targeted selected ion monitoring analyses, a mass inclusion list containing exact masses of target phenolic compounds was built and applied.

\subsubsection{Oxygen Radical Absorbance Capacity (ORAC) Assay}

The method reported by Cao et al. [76] was slightly modified and applied. The reaction mixture was prepared in a 96-well black microplate as follows: $160 \mu \mathrm{L}$ of $0.04 \mu \mathrm{M}$ Fluorescein in $0.075 \mathrm{M}$ Na-K phosphate buffer $\mathrm{pH}$ 7.0, $20 \mu \mathrm{L}$ of appropriately diluted extract or $20 \mu \mathrm{L}$ of $100 \mu \mathrm{M}$ Trolox used as control standard, or $20 \mu \mathrm{L}$ of extraction solvent as blank. Each mixture was kept $10 \mathrm{~min}$ at $37^{\circ} \mathrm{C}$ in the dark, and the reaction was started with

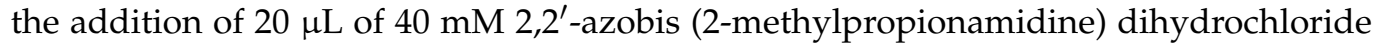
(AAPH). The fluorescence decay was measured at $37^{\circ} \mathrm{C}$ every $1 \mathrm{~min}$ at $485 \mathrm{~nm}$ excitation and $538 \mathrm{~nm}$ emission, using a Thermo Scientific Fluoroskan Ascent F2 Microplate. The ORAC value refers to the net area under the curve (AUC) of fluorescein decay in the 
presence of ginger extract or Trolox, subtracted of the blank area. The activity of the sample was expressed as $\mu \mathrm{mol}$ of Trolox Equivalents (TE)/g of FW, with the following equation (Equation (1)):

ORAC value $(\mu \mathrm{mol} \mathrm{TE} / \mathrm{g} \mathrm{FW})=\mathrm{k} \times \mathrm{a} \times \mathrm{h} \times\left[\left(\mathrm{S}_{\text {sample }}-\mathrm{S}_{\text {blank }}\right) /\left(\mathrm{S}_{\text {Trolox }}-\mathrm{S}_{\text {blank }}\right)\right]$

where $\mathrm{k}$ is the extract dilution; $\mathrm{a}$ is the ratio between the volume (liters) of the extract and grams of sample used for the extraction; $h$ is the final concentration of Trolox expressed as $\mu \mathrm{mol} / \mathrm{L}$; and $\mathrm{S}$ is the area under the curve of fluorescein in the presence of sample, Trolox, or blank.

\subsection{Cell Culture and Cytotoxicity Assay}

Mouse embryonic fibroblast cell line NIH-3T3 (Sigma-Aldrich) was cultured in Dulbecco's Modified Eagle Medium (DMEM)-high glucose supplemented with $100 \mathrm{U} / \mathrm{mL}$ penicillin, $100 \mu \mathrm{g} / \mathrm{mL}$ streptomycin, and $10 \%$ bovine calf serum at $37{ }^{\circ} \mathrm{C}$ in $5 \% \mathrm{CO}_{2}$ humidified atmosphere. NIH-3T3 cells were seeded into 96-well plates at a density of 104 cells per well in $100 \mu \mathrm{L}$ of growth medium, cultured for $24 \mathrm{~h}$, and then treated Fuji apple peel polyphenolic extract at final concentrations of $80,40,20,10$, or $5 \mu \mathrm{g} / \mathrm{mL}$. All treatments were performed for 24 and $48 \mathrm{~h}$ of incubation in triplicate. Cell viability was analyzed by the CellTiter $96^{\circledR}$ AQueous One Solution Cell Proliferation Assay (MTS assay, Promega, Milano, Italy) following the manufacturer's instruction. In brief, after cell treatments, $20 \mu \mathrm{L}$ of the MTS solution was added to each well and incubated with cells for $3 \mathrm{~h}$ at $37{ }^{\circ} \mathrm{C}, 5 \%$ $\mathrm{CO}_{2}$. The absorbance was read at $490 \mathrm{~nm}$ with the Bio-Rad iMarktm Microplate Reader (Promega, Milano, Italy). Cell viability was quantified as the percentage of viable cells using untreated cells as a control. All the experiments were repeated three times.

\section{5. $\kappa$-Casein Amyloid Formation}

A fresh stock solution of $\mathrm{K}$-casein in $50 \mathrm{mM}$ phosphate buffer $\mathrm{pH} 7.4$ was continuously stirred for $24 \mathrm{~h}$ and filtered through $0.22 \mu \mathrm{m}$ filters before using. As verified by dynamic light scattering, this procedure assures sample homogeneity but not reduction to monomeric species, which cannot be obtained due to the presence, in the $\mathrm{K}$-casein sample, of stable self-associating oligomeric micelle-like species [40]. The protein concentration was determined by recording the absorbance spectrum after filtering the sample by using an extinction coefficient at $280 \mathrm{~nm}$ of $0.95 \mathrm{mg}^{-1} \cdot \mathrm{mL} \cdot \mathrm{cm}^{-1}$ [39] and considering the purity of the sample $(70 \%)$ provided by Sigma Aldrich. $\mathrm{K}$-casein fibril formation is highly temperaturedependent [44]. To generate amyloid fibrils, all the experiments were performed incubating protein solutions at $50 \mu \mathrm{M}$ without shaking at the mammalian physiological temperature of $37^{\circ} \mathrm{C}$.

\subsection{Atomic Force Microscopy (AFM) Measurements}

AFM measurements were performed by using a Nanowizard III (JPK Instruments, Berlin, Germany) mounted on an Axio Observer D1 (Carl Zeiss, Berlin, Germany) or on an Eclipse Ti (Nikon, Tokyo, Japan) inverted optical microscope. Aliquots of protein solutions were deposited onto freshly cleaved mica surfaces (Agar Scientific, Assing S.P.A., Monterotondo, Roma, Italy) and incubated for up to $20 \mathrm{~min}$ before rinsing with deionized water and drying under a low-pressure nitrogen flow. Imaging of the protein was carried out in intermittent contact mode in air by using NCHR silicon cantilever (Nanoworld, Neuchâtel, Switzerland) with nominal spring constant ranging from 21 to $78 \mathrm{~N} / \mathrm{m}$ and typical resonance frequency ranging from 250 to $390 \mathrm{kHz}$.

\subsection{Thioflavin T (ThT) Spectrofluorometric Measurements}

ThT fluorescence emission was monitored by using a JASCO FP-6500 spectrometer (JASCO Corporation, Tokyo, Japan). The excitation and emission wavelengths were 450 and $485 \mathrm{~nm}$, respectively, with a slit width of $3 \mathrm{~nm}$. ThT concentration was $12 \mu \mathrm{M}$. $\mathrm{K}$-casein $(50 \mu \mathrm{M})$ was dissolved with the dye before being placed at $37^{\circ} \mathrm{C}$ in the thermostated cell 
compartment $(10 \mathrm{~mm})$. It is known that, upon binding to fibrils, ThT displays a dramatic shift of the excitation maximum (from $385 \mathrm{~nm}$ to $450 \mathrm{~nm}$ ) and of the emission maximum (from $445 \mathrm{~nm}$ to $482 \mathrm{~nm}$ ) [77]. Due to the binding of native $\mathrm{k}$-casein with Thioflavin T [40], data were presented as $\Delta \mathrm{F}$ in function of time, where $\Delta \mathrm{F}=\mathrm{F}-\mathrm{F}_{0}$ is the difference between the fluorescence reading value and $F_{0}$ the fluorescence value registered once samples reached thermal equilibrium at $37^{\circ} \mathrm{C}$, after about $20 \mathrm{~min}$.

\subsection{Congo Red Binding Assay}

The binding of Congo red was assessed by using absorption spectroscopy (Spectrophotometer Shimadzu UV2401PC, Tokyo, Japan). A 4 mM stock solution of Congo red (Sigma Aldrich) was prepared in $50 \mathrm{mM}$ phosphate buffer $\mathrm{pH}$ 7.4. Congo red solution $(20 \mu \mathrm{M})$ was mixed with $\mathrm{K}$-casein species $(50 \mu \mathrm{M})$ taken at the beginning and after $24 \mathrm{~h}$ of protein incubation at $37^{\circ} \mathrm{C}$ in the absence and in the presence of $40 \mu \mathrm{g} / \mathrm{mL}$ APP.

\section{9. $A \beta_{1-42}$ Peptide Amyloid Formation}

The synthetic peptide $A \beta_{1-42}$ (AnaSpec, Inc., Fremont, CA, USA) was solubilized in $\mathrm{NaOH} .5 \mathrm{mM}, \mathrm{pH}$ 10, and lyophilized according to Fezoui et al. protocol [78]. The lyophilized peptide was then dissolved in $50 \mathrm{mM}$ phosphate buffer $\mathrm{pH} 7.4$ and filtered with two filters in series of $0.20 \mu \mathrm{m}$ (Whatman, Merck KGaA, Darmstadt, Germany) and $0.02 \mu \mathrm{m}$ (Millex-LG, Merck KGaA, Darmstadt, Germany) respectively, in order to eliminate large aggregates. The sample preparation was operated in asepsis using a cold room at $4^{\circ} \mathrm{C}$. $\mathrm{A} \beta$ concentration was determined by tyrosine absorption at $276 \mathrm{~nm}$ using an extinction coefficient of $1390 \mathrm{~cm}^{-1} \cdot \mathrm{M}^{-1}$. The aggregation kinetics of $50 \mu \mathrm{M} \mathrm{A} \beta_{1-42}$ was monitored by light scattering after incubating the sample at controlled temperature $\left(37^{\circ} \mathrm{C}\right)[69,79]$. The samples containing $50 \mu \mathrm{M} \mathrm{A} \beta$ and APP were obtained by appropriate aseptic mixing of the protein solutions and placed in closed cuvettes in a cold room at $4{ }^{\circ} \mathrm{C}$, before incubation at higher temperatures. The aggregation kinetics was followed, as for the control, at a controlled temperature $\left(37^{\circ} \mathrm{C}\right)$ and under controlled stirring $(200 \mathrm{rpm})$ for $8 \mathrm{~h}$.

\subsection{Static and Dynamic Light Scattering}

The aggregation of proteins in the presence or absence of polyphenols was investigated by static and dynamic light scattering [80,81]. The samples were placed into a dust-free quartz cell without further filtering and kept at $37^{\circ} \mathrm{C}$ in the thermostatic cell compartment of a Brookhaven Instruments BI200-SM goniometer (Brookhaven Instruments, Holtsville, NY, USA). The temperature was controlled within $0.1^{\circ} \mathrm{C}$ using a thermostatic recirculating bath. The light scattered intensity and its autocorrelation function were measured at $\theta=90^{\circ}$ by using a Brookhaven BI-9000 correlator (Brookhaven Instruments, Holtsville, NY, USA) and a $50 \mathrm{~mW}$ He-Ne laser tuned at a wavelength $\lambda=632.8 \mathrm{~nm}$. Static light scattering data were corrected for the background scattering of the solvent and normalized by using toluene as a calibration liquid. The intensity $\mathrm{I}(\mathrm{q})$ is measured as kilo count per seconds kcps, referred to as average number of photons per second arriving at the detector.

Due to their Brownian motion, particles moving in solution give rise to fluctuations in the intensity of the scattered light. In a light scattering experiment carried out in dynamic modality, the autocorrelator measures the homodyne intensity-intensity correlation function that, for a Gaussian distribution of the intensity profile of the scattered light, is related to the electric field correlation function (Equation (2)):

$$
g^{(2)}(q, t)=\left[A+B g^{(1)}(q, t)\right]^{2}
$$

where $A$ and $B$ are the experimental baseline and the optical constant, respectively. For polydisperse particles, $g^{(1)}(q, t)$ is given by Equation (3):

$$
g^{(1)}(q, t)=\int_{0}^{\infty} G(\Gamma) \exp (-\Gamma t) d \Gamma
$$


Here, $G(\Gamma)$ is the normalized number distribution function for the decay constant $\Gamma=q^{2} D_{T}$, where $q=(4 \pi \mathrm{n} / \lambda) \sin (\theta / 2)$ is the scattering vector defining the spatial resolution with $\mathrm{n}$ and $D_{T}$ being the solvent refractive index and the translational diffusion coefficient, respectively. The hydrodynamic diameter $D_{H}$ is calculated from $D_{T}$ through the StokesEinstein relationship (Equation (4)):

$$
D_{T}=\frac{k_{B} T}{3 \pi \eta D_{H}}
$$

where $k_{B}$ is the Boltzmann constant, $\mathrm{T}$ is the absolute temperature, and $\eta$ is the solvent viscosity. $D_{H}$ was obtained by the intensity autocorrelation functions by means of the cumulant method [82].

\subsection{Circular Dichroism}

CD spectroscopic measurements were carried out at $20^{\circ} \mathrm{C}$ by using a JASCO J-810 spectrometer (JASCO Corporation, Tokyo, Japan) equipped with a temperature control unit. A quartz cell with a path length of $0.2 \mathrm{~mm}$ was used for FAR-UV (190-250 nm) measurements. Samples of $50 \mu \mathrm{M} \kappa$-casein in the presence and in the absence of different APP concentrations were incubated at $37^{\circ} \mathrm{C}$. Aliquots of $100 \mu \mathrm{L}$ were removed from each sample at the beginning and after $24 \mathrm{~h}$ of thermal incubation and quenched at $4{ }^{\circ} \mathrm{C}$ before CD experiments. Each CD spectrum was obtained by averaging over eight scans and subtracting the blank solvent contribution.

\section{Conclusions}

In this work, we demonstrated that the whole pool of polyphenols extracted from the peels of Fuji apple-a widespread apple variety-was effective in inhibiting the structural conversion accompanying the aggregation of $\mathrm{K}$-casein, a protein from bovine milk that forms amyloid fibrils under physiological conditions (neutral $\mathrm{pH}$ and $37^{\circ} \mathrm{C}$ ). Although more insights into the toxic properties of the protein species resulting from incubation with APP is required, we believe that our study lays the groundwork for considering a by-product of the apple food industry as a beneficial source for human health.

In fact, while the action of some individual polyphenols from apples on $\mathrm{k}$-casein and other amyloid proteins has been extensively proven, to our knowledge, the effect exerted by the pool of polyphenols extracted from apple peels (which, although rich in bioactive compounds, are normally considered as waste) has never been analyzed. Considering some common features between the A $\beta$ peptides involved in Alzheimer's Disease and K-casein amyloid structures, including the cross-beta spine of the inner core [70] and the potential role of micellar conformations [52,53], we also verified that APP inhibit the aggregation of the $A \beta_{1-42}$ peptide involved in Alzheimer's Disease.

Therefore, our study could provide the basis for further research on the pathology of the protein species resulted from the APP inhibitory action thus favoring the valorization of agriculture and food industry waste products for recycling and circular economy purposes. The Fuji cultivar was introduced in Sicily only recently [83], and new knowledge on its functional properties could incentive this cultivation and help to preserve apple biodiversity.

More generally, our study further confirms the importance of designing new therapeutic effective strategies in the neurodegeneration field based on natural compounds and of investigating functional food consumption for prevention and health purposes.

Supplementary Materials: The following are available online at. Figure S1: UHPLC-HESI-MS targeted single ion monitoring chromatogram obtained from Fuji apple peel phenolic extract, Figure S2: Effects of Fuji apple peel phenolic extract on NIH-3T3 cell viability. The cells were incubated for 24, 48 , and $72 \mathrm{~h}$ with the appropriate concentrations of phenolic extracts. At the end of incubation, cell viability was measured by MTS assay as described in Materials and Methods. Values are means \pm SD of cell viability calculated from at least three separate experiments, Figure S3: CD spectra of $50 \mu \mathrm{M}$ 
$\mathrm{K}$-casein at the beginning of the amyloid aggregation process (black) and after $24 \mathrm{~h}$ of incubation at $37^{\circ} \mathrm{C}$ (dashed black) in the presence of $5 \mu \mathrm{g} / \mathrm{mL}$ of APP (a); $10 \mu \mathrm{g} / \mathrm{mL}$ of APP (b); $20 \mu \mathrm{g} / \mathrm{mL}$ of $\operatorname{APP}(\mathrm{c})$.

Author Contributions: Conceptualization, V.G., M.A.C., F.L., M.A.G., and S.V.; methodology, V.G., G.C.R., M.A.C., F.L., V.D.S., and S.V.; investigation, G.C.R., M.R., and V.D.S.; data curation, G.C.R., M.A.C., F.L., and S.V.; writing-original draft preparation, V.G., G.C.R., M.A.C., and S.V. writingreview and editing, V.G., G.C.R., M.A.C., F.L., M.R., V.D.S., M.A.G., and S.V. All authors have read and agreed to the published version of the manuscript.

Funding: This work was supported by Italian grant FIRB “Future in research" RBFR12SIPT MIND: "Multidisciplinary Investigations for the development of Neuroprotective Drugs", by the Sicily Region grants CAFIS (PO FESR 2007-2014) and "Rafforzare l'occupabilità nel sistema R\&S e la nascita di spin off di ricerca in Sicilia" (P.O. FSE 2014/2020). This research was also financially supported by the Ph.D. Program Mediterranean Fruit Crops, Palermo University, Italy.

Data Availability Statement: Data are contained within the article and Supplementary Materials.

Acknowledgments: We express our sincere thanks to Donatella Bulone and Pier Luigi San Biagio for their critical suggestions. We are grateful to Rita Carrotta and Maria Rosalia Mangione for their scientific advice during the experiments and to Fabrizio Giambertone, Roberto Megna and Alessia Provenzano for their help and technical assistance.

Conflicts of Interest: The authors declare no conflict of interest. The funders had no role in the design of the study; in the collection, analyses, or interpretation of data; in the writing of the manuscript, or in the decision to publish the results.

Sample Availability: Samples of APP are available from the authors.

\section{Abbreviations}

$\begin{array}{ll}\text { APP } & \text { Apple Peel Polyphenols } \\ \text { CD } & \text { Circular Dichroism } \\ \text { LS } & \text { Light Scattering } \\ \text { ThT } & \text { Thioflavin T } \\ \text { TE } & \text { Trolox Equivalents } \\ \text { CTE } & \text { Catechin Equivalents } \\ \text { FW } & \text { Fresh Weight } \\ \text { AFM } & \text { Atomic Force Microscopy } \\ \text { FAR-UV } & \text { Far-UltraViolet } \\ \text { ORAC } & \text { Oxygen Radical Antioxidant Capacity } \\ \text { TPC } & \text { Total Polyphenol Content } \\ \text { CR } & \text { Congo Red }\end{array}$

\section{References}

1. Diacono, M.; Persiani, A.; Testani, E.; Montemurro, F.; Ciaccia, C. Recycling agricultural wastes and by-products in organic farming: Biofertilizer production, yield performance and carbon footprint analysis. Sustainability 2019, 11, 3824. [CrossRef]

2. Gulsunoglu, Z.; Purves, R.; Karbancioglu-Guler, F.; Kilic-Akyilmaz, M. Enhancement of phenolic antioxidants in industrial apple waste by fermentation with Aspergillus spp. Biocatal. Agric. Biotechnol. 2020, 25, 101562. [CrossRef]

3. Wolfe, K.L.; Liu, R.H. Apple peels as a value-added food ingredient. J. Agric. Food Chem. 2003, 51, 1676-1683. [CrossRef]

4. Wandjou, J.G.N.; Lancioni, L.; Barbalace, M.C.; Hrelia, S.; Papa, F.; Sagratini, G.; Vittori, S.; Dall'Acqua, S.; Caprioli, G.; Beghelli, D.; et al. Comprehensive characterization of phytochemicals and biological activities of the Italian ancient apple 'Mela Rosa dei Monti Sibillini'. Food Res. Int. 2020, 137, 109422. [CrossRef]

5. Lončarić, A.; Matanović, K.; Ferrer, P.; Kovač, T.; Šarkanj, B.; Skendrović Babojelić, M.; Lores, M. Peel of traditional apple varieties as a great source of bioactive compounds: Extraction by micro-matrix solid-phase dispersion. Foods 2020, 9, 80. [CrossRef]

6. Wolfe, K.; Wu, X.; Liu, R.H. Antioxidant activity of apple peels. J. Agric. Food Chem. 2003, 51, 609-614. [CrossRef] [PubMed]

7. Miura, T.; Chiba, M.; Kasai, K.; Nozaka, H.; Nakamura, T.; Shoji, T.; Kanda, T.; Ohtake, Y.; Sato, T. Apple procyanidins induce tumor cell apoptosis through mitochondrial pathway activation of caspase-3. Carcinogenesis 2008, 29, 585-593. [CrossRef] [PubMed] 
8. $\quad$ Akiyama, H.; Sato, Y.; Watanabe, T.; Nagaoka, M.H.; Yoshioka, Y.; Shoji, T.; Kanda, T.; Yamada, K.; Totsuka, M.; Teshima, R.; et al. Dietary unripe apple polyphenol inhibits the development of food allergies in murine models. FEBS Lett. 2005, 579, $4485-4491$. [CrossRef] [PubMed]

9. Sunagawa, T.; Shimizu, T.; Kanda, T.; Tagashira, M.; Sami, M.; Shirasawa, T. Procyanidins from apples (Malus pumila Mill.) extend the lifespan of Caenorhabditis elegans. Planta Med. 2011, 77, 122-127. [CrossRef] [PubMed]

10. Zhao, S.; Zhang, L.; Yang, C.; Li, Z.; Rong, S. Procyanidins and Alzheimer's disease. Mol. Neurobiol. 2019, 56, 5556-5567. [CrossRef] [PubMed]

11. Khan, H.; Ullah, H.; Aschner, M.; Cheang, W.S.; Akkol, E.K. Neuroprotective effects of quercetin in Alzheimer's disease. Biomolecules 2020, 10, 59. [CrossRef]

12. Boyina, H.K.; Geethakhrishnan, S.L.; Panuganti, S.; Gangarapu, K.; Devarakonda, K.P.; Bakshi, V.; Guggilla, S.R. In Silico and In Vivo Studies on Quercetin as Potential Anti-Parkinson Agent. In GeNeDis 2018: Advances in Experimental Medicine and Biology; Vlamos, P., Ed.; Springer: Cham, Switerlands, 2020; Volume 1195, pp. 1-11.

13. Phan, H.T.; Samarat, K.; Takamura, Y.; Azo-Oussou, A.F.; Nakazono, Y.; Vestergaard, M.D.C. Polyphenols modulate alzheimer's amyloid beta aggregation in a structure-dependent manner. Nutrients 2019, 11, 756. [CrossRef]

14. Carrell, R.W.; Lomas, D.A. Conformational disease. Lancet 1997, 350, 134-138. [CrossRef]

15. Makin, O.S.; Serpell, L.C. Examining the structure of the mature amyloid fibril. Biochem. Soc. Trans. 2002, 30, 521-525. [CrossRef] [PubMed]

16. Serpell, L.C.; Sunde, M.; Benson, M.D.; Tennent, G.A.; Pepys, M.B.; Fraser, P.E. The protofilament substructure of amyloid fibrils. J. Mol. Biol. 2000, 300, 1033-1039. [CrossRef] [PubMed]

17. Dobson, C.M. Protein folding and misfolding. Nature 2003, 426, 884-890. [CrossRef] [PubMed]

18. Koike, H.; Katsuno, M. Ultrastructure in Transthyretin Amyloidosis: From Pathophysiology to Therapeutic Insights. Biomedicines 2019, 7, 11. [CrossRef]

19. Koike, H.; Nishi, R.; Ikeda, S.; Kawagashira, Y.; Iijima, M.; Sakurai, T.; Shimohata, T.; Katsuno, M.; Sobue, G.J. The morphology of amyloid fibrils and their impact on tissue damage in hereditary transthyretin amyloidosis: An ultrastructural study. J. Neurol. Sci. 2018, 394, 99-106. [CrossRef]

20. Canale, C.; Seghezza, S.; Vilasi, S.; Carrotta, R.; Bulone, D.; Diaspro, A.; San Biagio, P.L.; Dante, S. Different effects of Alzheimer's peptide A $\beta$ (1-40) oligomers and fibrils on supported lipid membranes. Biophys. Chem. 2013, 182, 23-29. [CrossRef]

21. Walsh, D.M.; Klyubin, I.; Fadeeva, J.V.; Rowan, M.J.; Selkoe, D.J. Amyloid- $\beta$ oligomers: Their production, toxicity and therapeutic inhibition. Biochem. Soc. Trans. 2002, 30, 552-557. [CrossRef]

22. Vilasi, A.; Vilasi, S.; Romano, R.; Acernese, F.; Barone, F.; Balestrieri, M.L.; Maritato, R.; Irace, G.; Sirangelo, I. Unraveling amyloid toxicity pathway in NIH3T3 cells by a combined proteomic and $1 \mathrm{H}-\mathrm{NMR}$ metabonomic approach. J. Cell. Physiol. 2013, 228, 1359-1367. [CrossRef]

23. Choi, D.Y.; Lee, Y.J.; Hong, J.T.; Lee, H.J. Antioxidant properties of natural polyphenols and their therapeutic potentials for Alzheimer's disease. Brain Res. Bull. 2012, 87, 144-153. [CrossRef]

24. Ngoungoure, V.L.N.; Schluesener, J.; Moundipa, P.F.; Schluesener, H. Natural polyphenols binding to amyloid: A broad class of compounds to treat different human amyloid diseases. Mol. Nutr. Food Res. 2015, 59, 8-20. [CrossRef]

25. Stefani, M.; Rigacci, S. Beneficial properties of natural phenols: Highlight on protection against pathological conditions associated with amyloid aggregation. Biofactors 2014, 40, 482-493. [CrossRef]

26. Francioso, A.; Punzi, P.; Boffi, A.; Lori, C.; Martire, S.; Giordano, C.; D’Erme, M.; Mosca, L. $\beta$-sheet interfering molecules acting against $\beta$-amyloid aggregation and fibrillogenesis. Bioorg. Med. Chem. 2015, 23, 1671-1683. [CrossRef]

27. Porat, Y.; Abramowitz, A.; Gazit, E. Inhibition of amyloid fibril formation by polyphenols: Structural similarity and aromatic interactions as a common inhibition mechanism. Chem. Biol. Drug Des. 2006, 67, 27-37. [CrossRef]

28. Hudson, S.A.; Ecroyd, H.; Dehle, F.C.; Musgrave, I.F.; Carver, J.A. (-)-Epigallocatechin-3-gallate (EGCG) maintains k-casein in its pre-fibrillar state without redirecting its aggregation pathway. J. Mol. Biol. 2009, 392, 689-700. [CrossRef]

29. Wang, J.B.; Wang, Y.M.; Zeng, C.M. Quercetin inhibits amyloid fibrillation of bovine insulin and destabilizes preformed fibrils. Biochem. Biophys. Res. Commun. 2011, 415, 675-679. [CrossRef]

30. Ono, K.; Yoshiike, Y.; Takashima, A.; Hasegawa, K.; Naiki, H.; Yamada, M. Potent anti-amyloidogenic and fibril-destabilizing effects of polyphenols in vitro: Implications for the prevention and therapeutics of Alzheimer's disease. J. Neurochem. 2003, 87, 172-181. [CrossRef]

31. Toda, T.; Sunagawa, T.; Kanda, T.; Tagashira, M.; Shirasawa, T.; Shimizu, T. Apple Procyanidins Suppress Amyloid-Protein Aggregation. Biochem. Res. Int. 2011, 2011, 784698. [CrossRef]

32. Cui, L.; Zhang, Y.; Cao, H.; Wang, Y.; Teng, T.; Ma, G.; Li, Y.; Li, K.; Zhang, Y. Ferulic acid inhibits the transition of amyloid- $\beta 42$ monomers to oligomers but accelerates the transition from oligomers to fibrils. J. Alzheimers Dis. 2013, 37, 19-28. [CrossRef]

33. Iannuzzi, C.; Borriello, M.; Irace, G.; Cammarota, M.; Di Maro, A.; Sirangelo, I. Vanillin Affects Amyloid Aggregation and Non-Enzymatic Glycation in Human Insulin. Sci. Rep. 2017, 7, 15086. [CrossRef]

34. Ma, W.; Tribet, C.; Guyot, S.; Zanchi, D. Tannin-controlled micelles and fibrils of k-casein. Chem. Phys. 2019, 151, 245103. [CrossRef]

35. Hudson, S.A.; Ecroyd, H.; Kee, T.W.; Carver, J.A. The thioflavin T fluorescence assay for amyloid fibril detection can be biased by the presence of exogenous compounds. FEBS J. 2009, 276, 5960-5972. [CrossRef] [PubMed] 
36. Holt, C.; Sawyer, L. Caseins as rheomorphic proteins: Interpretation of primary and secondary structures of the $\alpha \mathrm{S} 1-, \beta$-and K-caseins. J. Chem. Soc. Faraday Trans. 1993, 89, 2683-2692. [CrossRef]

37. Thurn, A.; Burchard, W.; Niki, R. Structure of casein micelles I. Small angle neutron scattering and light scattering from $\beta$-and X-casein. Colloid Polym. Sci 1987, 265, 653-666. [CrossRef]

38. Vreeman, H.J.; Brinkhuis, J.A.; Van der Spek, C.A. Some association properties of bovine SH-k-casein. Biophys. Chem. 1981, 14, 185-193. [CrossRef]

39. McSweeney, P.L.; Fox, P.F. Advanced Dairy Chemistry: Volume 1A: Proteins: Basic Aspects; Springer Science \& Business Media: Berlin/Heidelberg, Germany, 2013.

40. Farrell, H.M.; Cooke, P.H.; Wickham, E.D.; Piotrowski, E.G.; Hoagland, P.D. Environmental influences on bovine k-casein: Reduction and conversion to fibrillar (amyloid) structures. J. Protein Chem. 2003, 22, 259-273. [CrossRef]

41. Ecroyd, H.; Koudelka, T.; Thorn, D.C.; Williams, D.M.; Devlin, G.; Hoffmann, P.; Carver, J.A. Dissociation from the oligomeric state is the rate-limiting step in fibril formation by k-casein. J. Biol. Chem. 2008, 283, 9012-9022. [CrossRef]

42. Ecroyd, H.; Thorn, D.C.; Liu, Y.; Carver, J.A. The dissociated form of k-casein is the precursor to its amyloid fibril formation. Biochem. J. 2010, 429, 251-260. [CrossRef]

43. Thorn, D.C.; Ecroyd, H.; Carver, J.A. The two-faced nature of milk casein proteins: Amyloid fibril formation and chaperone-like activity. Aust. J. Dairy Technol. 2009, 64, 34.

44. Leonil, J.; Henry, G.; Jouanneau, D.; Delage, M.M.; Forge, V.; Putaux, J.L. Kinetics of fibril formation of bovine k-casein indicate a conformational rearrangement as a critical step in the process. J. Mol. Biol. 2008, 381, 1267-1280. [CrossRef] [PubMed]

45. Thorn, D.C.; Meehan, S.; Sunde, M.; Rekas, A.; Gras, S.L.; MacPhee, C.E.; Dobson, C.M.; Wilson, M.R.; Carver, J.A. Amyloid fibril formation by bovine milk $\mathrm{k}$-casein and its inhibition by the molecular chaperones $\alpha$ S-and $\beta$-casein. Biochemistry 2005, 44, 17027-17036. [CrossRef]

46. Carrotta, R.; Canale, C.; Diaspro, A.; Trapani, A.; San Biagio, P.L.; Bulone, D. Inhibiting effect of $\alpha(\mathrm{s} 1)$-casein on A $\beta(1-40)$ fibrillogenesis. Biochim. Biophys. Acta Gen. Subj. 2012, 1820, 124-132. [CrossRef]

47. Carrotta, R.; Vilasi, S.; Librizzi, F.; Martorana, V.; Bulone, D.; San Biagio, P.L. $\alpha$-Casein inhibition mechanism in concanavalin A aggregation process. J. Phys. Chem. B 2012, 116, 14700-14707. [CrossRef]

48. Librizzi, F.; Carrotta, R.; Spigolon, D.; Bulone, D.; San Biagio, P.L. $\alpha$-Casein inhibits insulin amyloid formation by preventing the onset of secondary nucleation processes. J. Phys. Chem. Lett. 2014, 5, 3043-3048. [CrossRef]

49. Feng, B.Y.; Toyama, B.H.; Wille, H.; Colby, D.W.; Collins, S.R.; May, B.C.; Prusiner, S.B.; Weissman, J.; Shoichet, B.K. Small-molecule aggregates inhibit amyloid polymerization. Nat. Chem. Biol. 2008, 4, 197-199. [CrossRef]

50. Kumosinski, T.F.; Brown, E.M.; Farrell, H.M., Jr. Three-dimensional molecular modeling of bovine caseins: A refined, energyminimized k-casein structure. J. Dairy Sci. 1993, 76, 2507-2520. [CrossRef]

51. Jain, N.; Bhattacharya, M.; Mukhopadhyay, S. Chain collapse of an amyloidogenic intrinsically disordered protein. Biophys. J. 2011, 101, 1720-1729. [CrossRef]

52. Sabaté, R.; Estelrich, J.J. Evidence of the existence of micelles in the fibrillogenesis of beta-amyloid peptide. Phys. Chem. B 2005, 109, 11027-11032. [CrossRef]

53. Morel, B.; Hingant, E.; Fontes, P.; Alvarez-Martinez, M.T.; Arnaud, J.D.; Liautard, J.P.; Pujo-Menjouet, L.; Hingant, E.; Fontes, P.; Alvarez-Martinez, M.T; et al. Dynamic micellar oligomers of amyloid beta peptides play a crucial role in their aggregation mechanisms. Phys. Chem. Chem. Phys. 2018, 20, 20597-20614. [CrossRef]

54. Hingant, E.; Fontes, P.; Alvarez-Martinez, M.T.; Arnaud, J.D.; Liautard, J.P.; Pujo-Menjouet, L. A micellar on-pathway intermediate step explains the kinetics of prion amyloid formation. PLoS Comput. Biol. 2014, 10, e1003735. [CrossRef]

55. Liu, R.H. Health benefits of fruit and vegetables are from additive and synergistic combinations of phytochemicals. Am. J. Clin. Nutr. 2003, 78, 517S-520S. [CrossRef]

56. Prior, R.L. Oxygen radical absorbance capacity (ORAC): New horizons in relating dietary antioxidants/bioactives and health benefits. J. Funct. Foods 2015, 18, 797-810. [CrossRef]

57. Jairath, G.; Chatli, M.K.; Biswas, K. Comparative Study on In vitro and In vivo Evaluation of Antioxidant Potential of Apple Peel Extract and Aloe Vera Gel. J. Food Process. Preserv. 2016, 40, 607-614. [CrossRef]

58. Bitalebi, S.; Nikoo, M.; Rahmanifarah, K.; Noori, F.; Gavlighi, H.A. Effect of apple peel extract as natural antioxidant on lipid and protein oxidation of rainbow trout (Oncorhynchus mykiss) mince. Int. Aquat. Res. 2019, 11, 135-146. [CrossRef]

59. He, R.R.; Wang, M.; Wang, C.Z.; Chen, B.T.; Lu, C.N.; Yao, X.S.; Chen, J.X.; Kurihara, H.J. Protective effect of apple polyphenols against stress-provoked influenza viral infection in restraint mice. Agric. Food Chem. 2011, 59, 3730-3737. [CrossRef]

60. Xu, Z.R.; Li, J.Y.; Dong, X.W.; Tan, Z.J.; Wu, W.Z.; Xie, Q.M.; Yang, Y.M. Apple Polyphenols Decrease Atherosclerosis and Hepatic Steatosis in ApoE-/- Mice through the ROS/MAPK/NF-кB Pathway. Nutrients 2015, 7, 7085-7105. [CrossRef]

61. Ogino, Y.; Osada, K.; Nakamura, S.; Ohta, Y.; Kanda, T.; Sugano, M. Absorption of dietary cholesterol oxidation products and their downstream metabolic effects are reduced by dietary apple polyphenols. Lipids 2007, 42, 151-161. [CrossRef]

62. Levine, H., III. Thioflavine T interaction with synthetic Alzheimer's disease $\beta$-amyloid peptides: Detection of amyloid aggregation in solution. Protein Sci. 1993, 2, 404-410. [CrossRef]

63. Hawe, A.; Sutter, M.; Jiskoot, W. Extrinsic fluorescent dyes as tools for protein characterization. Pharm. Res. 2008, 25, 1487-1499. [CrossRef] 
64. Leibiger, C.; Kosyakova, N.; Mkrtchyan, H.; Glei, M.; Trifonov, V.; Liehr, T. First molecular cytogenetic high resolution characterization of the NIH $3 \mathrm{~T} 3$ cell line by murine multicolor banding. J. Histochem. Cytochem. 2013, 61, 306-312. [CrossRef] [PubMed]

65. Sirangelo, I.; Iannuzzi, C.; Vilasi, S.; Irace, G.; Giuberti, G.; Misso, G.; D’Alessandro, A.; Abbruzzese, A.; Caraglia, M. W7FW14F apomyoglobin amyloid aggregates-mediated apoptosis is due to oxidative stress and AKT inactivation caused by Ras and Rac. J. Cell. Physiol. 2009, 221, 412-423. [CrossRef] [PubMed]

66. Iannuzzi, C.; Vilasi, S.; Portaccio, M.; Irace, G.; Sirangelo, I. Heme binding inhibits the fibrillization of amyloidogenic apomyoglobin and determines lack of aggregate cytotoxicity. Protein Sci. 2007, 16, 507-516. [CrossRef]

67. Coelho-Cerqueira, E.; Pinheiro, A.S.; Follmer, C. Pitfalls associated with the use of Thioflavin-T to monitor anti-fibrillogenic activity. Bioorg. Med. Chem. Lett. 2014, 24, 3194-3198. [CrossRef]

68. Frid, P.; Anisimov, S.V.; Popovic, N. Congo red and protein aggregation in neurodegenerative diseases. Brain Res. Rev. 2007, 53, 135-160.

69. Vilasi, S.; Carrotta, R.; Ricci, C.; Rappa, G.C.; Librizzi, F.; Martorana, V.; Ortore, M.G.; Mangione, M.R. Inhibition of A $\beta_{1-42}$ Fibrillation by Chaperonins: Human Hsp60 Is a Stronger Inhibitor than Its Bacterial Homologue GroEL. ACS Chem. Neurosci. 2019, 10, 3565-3574. [CrossRef]

70. Petkova, A.T.; Ishii, Y.; Balbach, J.J.; Antzutkin, O.N.; Leapman, R.D.; Delaglio, F.; Tycko, R. A structural model for Alzheimer's $\beta$-amyloid fibrils based on experimental constraints from solid state NMR. Proc. Natl. Acad. Sci. USA 2002, 99, 16742-16747. [CrossRef]

71. Stsiapura, V.I.; Maskevich, A.A.; Kuzmitsky, V.A.; Turoverov, K.K.; Kuznetsova, I.M. Computational study of thioflavin T torsional relaxation in the excited state. J. Phys. Chem. A 2007, 111, 4829-4835. [CrossRef]

72. Chu, G.C.L.; Wilson, K. Evaluating Maturity of Empire, Idared and Spartan Apples. Factsheet-Ontario. Ministry of Agriculture, Food and Rural Affairs. Order No. 00-027. March 2000. Available online: http://www.omafra.gov.on.ca/english/crops/facts/00 -027.htm (accessed on 13 February 2021).

73. Ceymann, M.; Arrigoni, E.; Scharer, H.; Bozzi Nising, A.; Hurrell, R.F. Identification of apples rich in health-promoting flavan-3-ols and phenolic acids by measuring the polyphenol profile. J. Food Compos. 2012, 26, 128-135. [CrossRef]

74. Di Stefano, V.; Pitonzo, R.; Novara, M.E.; Bongiorno, D.; Indelicato, S.; Gentile, C.; Avellone, G.; Bognanni, R.; Scandurra, S.; Melilli, M.G. Antioxidant activity and phenolic composition in pomegranate (Punica granatum L.) genotypes from south Italy by UHPLC-Orbitrap-MS approach. J. Sci. Food Agric. 2019, 99, 1038-1045. [CrossRef] [PubMed]

75. Di Stefano, V.; Melilli, M.G. Effect of storage on quality parameters and phenolic content of Italian extra-virgin olive oils. Nat. Prod. Res. 2020, 34, 78-86. [CrossRef] [PubMed]

76. Cao, G.; Alessio, H.M.; Cutler, R.G. Oxygen-radical absorbance capacity assay for antioxidants. Free Radic. Biol. Med. 1993, 14, 303-311. [CrossRef]

77. Higuchi, K.; Hosowaka, M.; Takeda, T. Fluorometric determination of amyloid fibrils in vitro using the fluorescent dye, thioflavin T1. Anal. Biochem. 1989, 177, 244-249.

78. Fezoui, Y.; Hartley, D.M.; Harper, J.D.; Khurana, R.; Walsh, D.M.; Condron, M.M.; Selkoe, D.J.; Lansbury, P.T., Jr.; Fink, A.L.; Teplow, D.B. An improved method of preparing the amyloid beta-protein for fibrillogenesis and neurotoxicity experiments. Amyloid 2000, 7, 166-178. [CrossRef]

79. El-Agnaf, O.M.; Mahil, D.S.; Patel, B.P.; Austen, B.M. Oligomerization and toxicity of beta-amyloid-42 implicated in Alzheimer's disease. Biochem. Biophys. Res. Commun. 2000, 273, 273-1007. [CrossRef]

80. Pusey, P.N. Introduction to scattering experiments. In Neutrons, X-rays, and Light: Scattering Methods Applied to Soft Condensed Matter; Zemb, T., Lindner, P., Eds.; Elsevier: Amsterdam, The Netherlands, 2002.

81. Berne, B.J.; Pecora, R. Dynamic Light Scattering; John Wiley: New York, NY, USA, 1976.

82. Stepanek, P. The method and some applications. In Dynamic Light Scattering; Brown, W., Ed.; Clarendon Press: Oxford, UK, 1993.

83. Francaviglia, D.; Farina, V.; Avellone, G.; Lo Bianco, R. Fruit yield and quality responses of apple cvars Gala and Fuji to partial rootzone drying under Mediterranean conditions. J. Agric. Sci. 2013, 151, 556-569. [CrossRef] 